\title{
VARIABILITY IN SENSORY ECOLOGY: EXPANDING THE BRIDGE BETWEEN PHYSIOLOGY AND EVOLUTIONARY BIOLOGY
}

\author{
Olivier Dangles*
}

IRD, UR 072, LEGS, UPR 9034, CNRS 91198 Gif-sur-Yvette Cedex, France and Université Paris-Sud 11, 91405 Orsay Cedex, France

E-MAIL:DANGLES@LEGS.CNRS-GIF.FR

\section{DUNCAN IRSCHICK}

Department of Biology, University of Massachusetts at Amherst, Amherst, Massachusetts 01003 USA

E-MAIL: IRSCHICK@BIO.UMASS.EDU

\section{LARS CHITTKA}

Queen Mary University of London, Research Centre for Psychology, School of Biological and Chemical Sciences, London E1 4NS, United Kingdom

E-MAIL: L.CHITTKA@QMUL.AC.UK

JÉRÔME CASAS

Institut de Recherche en Biologie de l'Insecte, IRBI, UMR CNRS 6035, Université de Tours, 37200 Tours, France

E-MAIL: CASAS@UNIV-TOURS.FR

KEYWORDS

sensory ecology, phylogeny, ontogeny, populations, environmental changes, field experiments, adaptation, invertebrates, vertebrates

\section{ABSTRACT}

Sensory organs represent the interface between the central nervous system of organisms and the environment in which they live. To date, we still lack a true integration of ecological and evolutionary perspectives in our understanding of many sensory systems. We argue that scientists working in sensory ecology should expand the bridge between sensory and evolutionary biology, and, in working toward this goal, we advocate a combination of the experimental rigor of the sensory physiologist with population-based as well as evolutionary views.

*Present address: Pontificia Universidad Catolica del Ecuador, Facultad de Ciencias Exactas y Naturales, Laboratorio de Entomologia, Quito, Ecuador

The Quarterly Review of Biology, March 2009, Vol. 84, No. 1

Copyright (c) 2009 by The University of Chicago. All rights reserved.

0033-5770/2009/8401-0003\$15.00 


\section{INTRODUCTION}

THE RISE OF SENSORY ECOLOGY

$\mathrm{V}$ IRTUALLY ALL BEHAVIORAL decisions are based on information transmitted through sensory systems. During the past fifty years, numerous studies have successfully investigated the mechanistic bases of sensory systems using approaches from physiology, functional morphology, and neuroethology (e.g., Barlow and Mollon 1982; Smith 2000; Barth 2002; Greenfield 2002). The increasing interest among biologists in matters concerning sensory information in nature has resulted in the emergence of sensory ecology-the study of how organisms acquire and respond to information about their environment (Ali 1978; Dusenbery 1992; Chittka and Thomson 2001). Visual ecology (e.g., Lythgoe 1979; Partridge 1989; Endler 1992; Bowmaker et al. 1994; Archer et al. 1999; Briscoe and Chittka 2001; Browman and Hawryshyn 2001; Eckert and Zeil 2001; Hart 2001a; Théry and Casas 2002; Land and Nilson 2002; Cronin 2006; Zeil and Hemmi 2006; Rosenthal 2007) and chemical ecology (e.g., Sondheimer et al. 1970; Silverstein 1981; Bell and Cardé 1984; Pasteels et al. 1983; Hay and Fenical 1988; Duvall et al. 1986; Vet and Dicke 1992; Eisner and Meinwald 1995; Koehl et al. 2001; Cardé and Millar 2004; Romeo 2005; Müller-Schwarze 2006; Dicke and Takken 2006; Avilla et al. 2008; Witzgall et al. 2008) have played a central role in the development of sensory ecology into its own field of research. Other key examples of wellstudied sensory systems include echolocation in bats and dolphins (Thomas et al. 2002), electroreception in fish (Bullock et al. 2005; Arnegard and Carlson 2005; Snyder et al. 2007), hearing in frogs and insects (Wilczynski and Ryan 1988; Wiese and Gribakin 1992; Fullard and Yack 1993; Römer 1998; Stumpner and von Helversen 2001; Gerhardt and Huber 2002; Triblehorn and Yager 2005; Neuhofer et al. 2008), mechanoreception in arthropods (Barth 2002; Suter 2003; Fields and Weissburg 2005; Triblehorn and Yager 2006), and magnetic field reception in birds and rodents (Kimchi et al. 2004; Biro et al. 2007), all of which have been examined in an ecological context. Sensory ecology has grown rapidly over the past decade, in part because of rapid technological advances, such as high-speed cameras (Buskey and Hartline 2003; Dangles et al. 2007), field portable spectrometers (Cronin and Shashar 2001; Smith et al. 2003; Johnsen 2007; Ryan 2007), panoramic image devices (Zeil et al. 2003), acoustic flight path tracking (Jones and Holderied 2007), particle image velocimetry (Stacey et al. 2002; Casas et al. 2008), mathematical simulations (Humphrey et al. 1993; Chittka 1996a; Magal et al. 2006), and neural networks (Phelps 2007). Sensory ecology has also been incorporated into diverse areas of biology such as conservation biology (Rabin et al. 2003; Slabbekoorn and Ripmeester 2008) and biomimetics (Peremans and Reijniers 2005; Krijnen et al. 2006).

\section{THE NEED TO BRIDGE SENSORY AND EVOLUTIONARY BIOLOGY}

Sensory ecology has traditionally focused on the experimental and mechanistic study of the physiology and neuroethology of sensory organs. In the last two decades, the integration of ecological and evolutionary concepts into sensory ecology studies has been unequal among sensory modalities. The study of some sensory modalities, such as bird and fish vision or amphibian audition, has been guided by evolutionary biologists who have focused their interest on interactions between organisms and their conspecifics, food resources, and predators (e.g., Ryan 1990; Endler 1992; Kroodsma and Miller 1996; Gerhardt and Huber 2002; Baugh et al. 2008). Most of this research is concerned with the evolution of behavior, and it was performed by comparing sensory traits among populations or species living in different habitats (e.g., Endler et al. 2001; Cummings 2007) within the context of animal communication rather than sensory ecology, per se. This has resulted in the incorporation of sensory traits into several evolutionary theories, such as sexual selection and speciation (e.g., Ryan 1983; Ryan 1990; Endler 
1992; Yokoyama and Yokoyama 1996; Endler and Basolo 1998; Boughman 2002; Siemers and Schnitzler 2004; Gerhardt 2005; Stuart-Fox et al. 2007). However, this approach has so far focused mainly on vision, audition, and echolocation in vertebrates, and the mechanisms involved in the evolution of these sensory processes are often poorly understood (see Fuller et al. 2005). Research on other sensory modalities, such as invertebrate mechanoreception or olfaction, has been led by sensory physiologists who are mostly concerned with the mechanisms that enable an animal to produce and use signals in their environment (e.g., Barth and Schmid 2001). Comparative sensory physiology has always stressed the diversity of sensory systems and how it relates to behavior and ecology (e.g., Land 1989; Hart 2001b; Manley et al. 2004; Lukowiak and Weeks 2008), but the majority of these studies have remained rooted in studying how sensors function while directing less attention to the ecological and evolutionary meaning of sensory-trait variability and the role of sensors in nature (Hueter 1991; Chittka and Briscoe 2001; Bargmann 2006; Dangles et al. 2006b).

Scientists working in sensory ecology should work towards the fusion of these physiological and evolutionary approaches by addressing how key gaps can be filled between existing knowledge in sensory physiology and evolutionary biology. We argue that, for many sensory modalities (e.g., mechanoreception in the vastly diverse group of invertebrates), there is a dearth of in-depth studies uniting sensory and evolutionary biology. In this paper, we will propose a more integrated perspective toward sensory ecology that focuses on the study of variability in sensory traits at different levels, and, in order to do so, we will stress three themes that represent areas for growth: variability among species (phylogenetic history), variability among individuals/populations, and variability among developmental stages (ontogenetic changes). Finally, we will advocate a combination of the experimental rigor that is essential to sensory physiology with a more populationbased view that welcomes sensory variation as the raw material for natural selection to operate upon.

\section{Sensory Variability at Different LEVELS \\ VARIABILITY BETWEEN SPECIES}

Several studies have successfully used phylogenetic methods to study the evolution of sensory systems, investigating, for example, the phylogenetic position of sensory organs among clades-mainly above the family level-as well as the origin and evolution of particular sensory features inherent to each lineage, such as vision and olfaction (McFarland and Munz 1975; Chittka 1996b; Briscoe 1998; Oakley and Cunningham 2002; Spaethe and Briscoe 2004; Bowmaker and Hunt 2006; Plachetzki and Oakley 2007; Gustafsson et al. 2008), acoustics (Lakes-Harlan et al. 1999; Ryan and Rand 1999; Wilczynski et al. 2001), electroreception (Alves-Gomes 2001; Zakon 2008), and echolocation (Springer et al. 2001; Jones and Holderied 2007; Gardiner et al. 2008; Li et al. 2008). However, our knowledge about how sensory systems have diverged in both form and functional properties at the species level remains fragmentary and, to date, is limited to a handful of studies that have investigated relationships between the evolutionary development of species and the efficiency of their communication signals (e.g., Parker et al. 1998; Prum and Torres 2003; Smith et al. 2004; Wickham et al. 2006; Cummings 2007; Douglas et al. 2007; Briscoe 2008; Lavoué et al. 2008; Yager and Svenson 2008). Some of these studies have used phylogenetic methods to infer the ancestral sensory conditions of extant species and have then tested whether evolution has occurred in the predicted direction upon invasion of new habitats. For example, Cummings (2007) quantified the evolutionary direction of a sensory trade-off in a surfperch visual system by examining the direction of visual pigment divergence across extant taxa relative to the ancestral condition (Figure 1). Sensory bias was evaluated based on the ability of surfperch to detect a major foraging target (red algae) against background light. The divergence of estimated sensory perfor- 

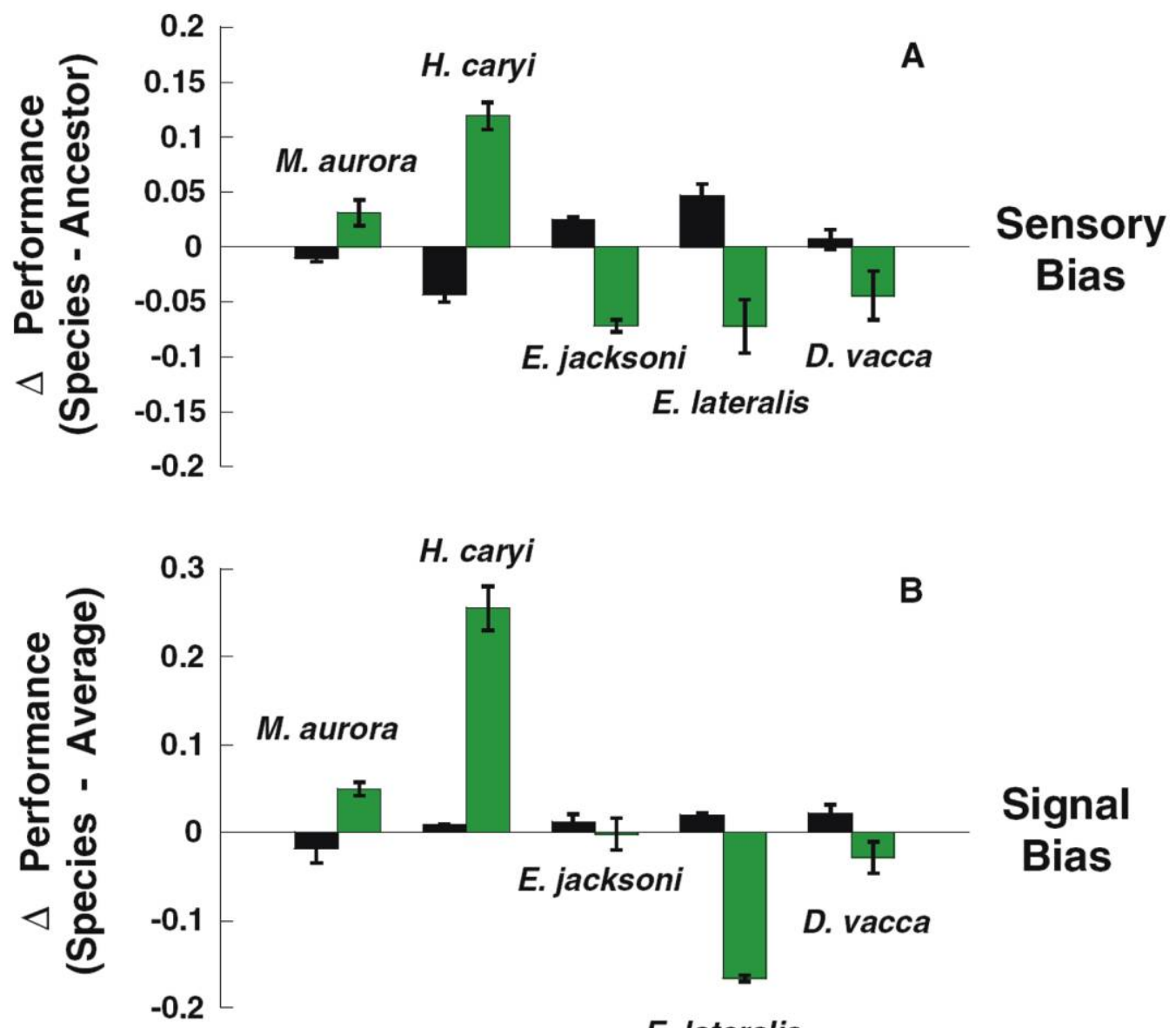

\section{E. lateralis}

M. aur. H. car. E. jac. E. lat. D. vac.

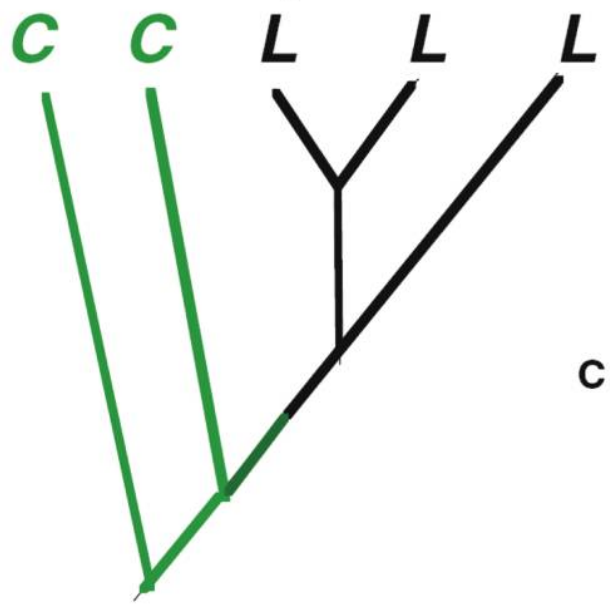

Figure 1 
mance relative to the ancestor was predicted by species-specific habitat characteristics: deeper dwelling surfperch in the California kelp forest habitat have diverged toward luminance-biased visual systems, whereas species occupying habitats with higher intensities and higher luminance variability have diverged to favor chromatic detection. This study supports the well-documented variation in the visual systems of aquatic species (Levene and McNichol 1979; Lythgoe 1984). By contrast, in a phylogenetic study of Hymenopteran visual systems, Chittka (1996a) found relatively little variation in photoreceptor spectral sensitivity, with no obvious congruence between visual system properties and lifestyle. Other research has shown relatively high conservation of visual systems in spite of divergent lifestyles in other terrestrial groups, such as primates (Pichaud et al. 1999), butterflies (Frentiu et al. 2007), and spiders ( $\mathrm{Su}$ et al. 2007). Evidence of both divergence and conservation in animal visual systems suggests that different habitats have yielded different patterns of divergence in vision. In particular, marine and freshwater systems with different light habitats are associated with large-scale divergence, whereas visual systems that have evolved in terrestrial environments are less diverse. Almong the same line, Devarakonda et al. (1996) and Humphrey et al. (2001) argued that the evolution of fluidmotion mechanoreceptors in arthropods may differ in aquatic and terrestrial hab- itats due to different physical constraints associated with fluid viscosity.

Phylogenetic approaches are powerful tools for researchers seeking to explore how different habitats have driven the evolution of sensory systems at the species level. In light of this, it is imperative that biologists tackle other important issues as well, such as the concept of specialization (see Irschick et al. 2005). In some cases, the expansion of the number of sensory receptors should increase the repertoire of signals that species detect, allowing them to occupy new niches. In other cases, evolution might favor a reduction/specialization in the repertoire of sense organs, receptors, and associated components of signal transduction when they no longer provide a selective advantage. For example, cavefish possess only tiny rudimentary eyes, which in adults are deeply sunken below the body surface after a process of ontogenetic regression (Wilkens and Meyer 1992). Retinas of deep-sea fishes frequently have reduced or lost the cone photoreceptors that are used for color vision in diurnal vertebrates (Warrant 2004). In jumping spiders (Salticidae), the evolution of multiple eye pairs may have enabled frontal eyes to become specialized for the task of orientation and spatial resolution, therefore increasing prey discrimination (Dacke et al. 2003). The selective advantage of having specialized versus generalized sensory systems remains a relatively unexplored field of sensory ecology (but see Bowmaker 1983; Morgan et al. 1992; Bernays and

Figure 1. Visual Detection Performance in FIve Surfperch Species

(A) Trade-offs in visual detection performance between luminance (i.e., brightness, in black) and chromatic (i.e., color, in green) detection across five dichromatic surfperch species occupying optically diverse habitats in the California kelp forest (see Cummings 2007 for more details on sensory bias estimation). Species that diverged from their ancestor in a direction that enhanced chromatic detection (H. caryi, M. aurora) also exhibited losses in the luminance channel, while species that gained in luminance detection (E. jacksoni, E. lateralis, and D. vacca) exhibited losses in chromatic detection. (B) Surfperch color patterns exhibit biases in detectability that match the visual detection bias of each species. For example, surfperch species with photoreceptor sensitivity favoring luminance detection (E. jacksoni, E. lateralis, and D. vacca) have color patterns with reflectance properties that have diverged to enhance the luminance channel. (C) A surfperch phylogenetic tree modified from Bernardi and Bucciarelli (1999), with branch color indicating chromatic (green) or luminance (black) visual detection performance estimates. Surfperch male color pattern signal properties are mapped onto the extant tips of the tree and indicate reflectance property signal bias for chromatic (green, C) and luminance (black, L). (From Cummings 2007; reproduced with permission from Blackwell.) 
Wcislo 1994), and further research in this area is encouraged.

\section{VARIABILITY BETWEEN INDIVIDUALS / POPULATIONS}

Comparative studies on population variability in phenotypes and the performance of sensory systems are attractive, as they can be directly related to mechanisms and patterns of the evolution of quantitative traits (see Arnold 1983; Endler et al. 2001; Raine et al. 2006). Many studies have pointed to the existence of intraspecific variation in the structure and/or performance of sensory systems-such as vertebrate vision (Lythgoe 1984; Archer et al. 1987; McDonald and Hawryshyn 1995; Fuller et al. 2003; Siddiqi et al 2004), invertebrate vision (Cronin et al. 2002; Spaethe and Chittka 2003), vertebrate acoustics (Kroodsma and Miller 1996; McClelland et al. 1998; Boul and Ryan 2004), insect acoustics (von Helversen et al. 2004), insect chemoreception (Löfstedt et al. 1985; Hansson et al. 1990; Chapman and Lee 1991; Anderbrant et al. 2000; Opstad et al. 2004), and bat echolocation (Guillén et al. 2000; Kingston and Rossiter 2004) — of populations living in different environments. With regard to vision specifically, the role of ecological divergence among populations has been highlighted over the last decade through Endler's (1992) sensory drive hypothesis. In many taxa (e.g., fish, birds, lizards), vision is intimately involved with mate recognition systems, and therefore potentially under strong selection pressure (Endler and Basolo 1998; Endler et al. 2001; Boughman 2002; Cummings 2007, Seehausen et al. 2008). This is also true for olfaction in many insects (e.g., Wyatt 2003). Assuming that easily detectable signals are likely to be favored by natural selection, the sensory drive hypothesis stipulates that when populations occupy new habitats in which the visual environment is different from their original environment, natural selection favors phenotypic change in the signal to maximize the effectiveness of communication, both intra- and interspecifically (Endler 1992). Endler et al. (2001) performed artificial selection experiments on the color sensitivity of the visual systems in four laboratory populations of guppies (Poecilia reticulata). They found a significant response to selection in all four selected populations, as well as significant heritability for color sensitivity, thus showing that the occupation of different visual environments leads to diversity in vision, which might, in turn, lead to divergence in visual signals.

The influence of the sensory drive hypothesis on animal sensory performance is likely to be important outside the context of mate choice, especially in regard to such activities as the detection of predators or the procurement of food, but this line of research has barely been explored (but see Dicke and Grostal 2001 for the chemical detection of natural enemies by arthropods; Neuweiler 1989 for the role of hearing in bat foraging ecology; Dominy et al. 2001 and Regan et al. 2001 for the perception of visible light by primates to assess the edibility of food items). Dangles et al. (2005) quantified the natural phenotypic variation in structure and performance of the air-flow sensing cercal system in five cricket populations from diverse habitats and predator communities. These cricket populations differed markedly from one another, such as in the total number of air-flow sensitive hairs and in the number of hairs longer than $1000 \mu \mathrm{m}$-the hairs most sensitive for the perception of predatory air flow signals. These phenotypic differences translated into differences in sensory performance: the most sensitive cricket population could perceive an approaching flying predator at a $20 \%$ greater distance than the less sensitive populations. As a possible explanation, the influence of habitat structure on air flow signal transmission (see Bradbury and Vehrencamp 1998; Roemer 1998) or the inducible response of insects to predation pressure (e.g., Weisser et al. 1999) may act on cricket populations that often show high degrees of reproductive isolation (Mousseau and Roff 1989). Sensory differences among populations can also lead to differences in how animals access food. Chittka et al. (2004) found that eight different populations of bumblebees from continental and Mediterranean Europe differ in a variety of 


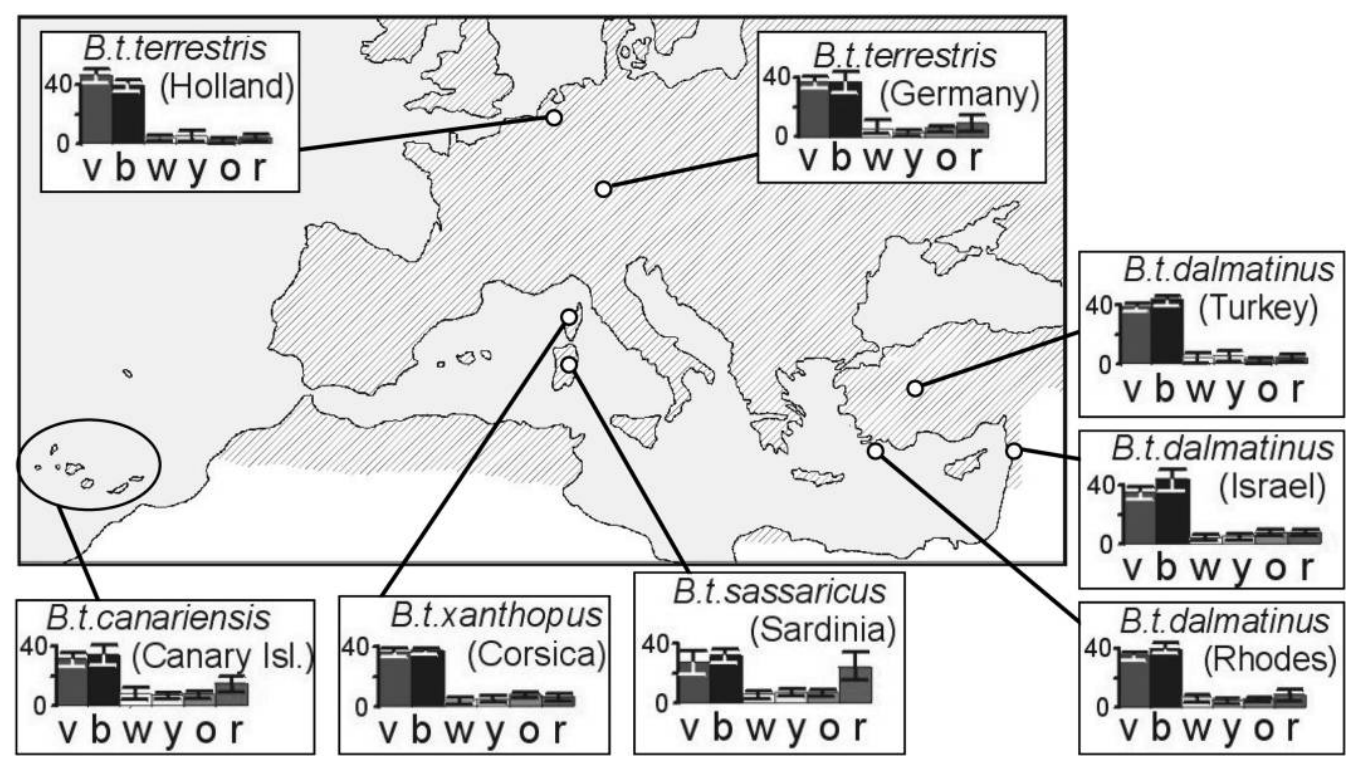

Figure 2. Biogeography of Floral Color Preference in Bombus terrestris (Hymenoptera)

Bees were individually offered the colors: V - violet (bee UV-blue); B - blue (bee blue); W - white (bee blue-green); $\mathrm{Y}$ - yellow; $\mathrm{O}$ - orange; $\mathrm{R}$ - red (the latter three are bee green). Column height denotes the mean percentage $( \pm 1 \mathrm{SE})$ of colony choices. At least five colonies were tested per population. The shaded area shows the distribution of B. terrestris (Rasmont et al. 2008). (Data from Chittka et al. 2001, 2004; figure from Raine et al. 2006, reproduced with permission from Elsevier.)

behavioral traits, with no apparent relation to differences in the environment (Figure 2 ). One of the traits they investigated was the innate flower color preference of worker bees, as it is easily quantifiable in laboratory-raised individuals. Other studies had found adaptive differences among species as well as colonies. For instance, Raine et al. (2006) observed that the nectar-robbing visitor of hummingbird flowers, Bombus occidentalis, has an innate red preference that is not shared by any other species, and Raine and Chittka (2007) observed that colonies with a stronger preference for violet flowers foraged more efficiently. While a comparison between populations-including several from islands-revealed overall similarities in color preference (i.e., all populations prefer colors in the violet to blue range), there was also significant variation between populations (e.g., members of the Sardinian and Tenerife populations showed a secondary preference for the color red [Chittka et al. 2004]) and subtle between-population variation in receptor tuning (Skorupski et al.
2007). However, this variation was apparently not related to differences in the "flower markets" in which these populations occurred. The authors considered several alternatives-for example, the possibility that food color preference is pleiotropically linked to mating preference (e.g., Smith et al. 2004) - but none of them provided convincing explanations. They therefore concluded that genetic drift processes, especially on islands, might have produced the observed between-population differences.

Understanding why variability in perceptual capabilities exists could be important for predicting ecological outcomes of optimal foraging theory; any delay in recognition of a danger or food resource and the perception of its energetic costs or values is likely to influence optimal decisions by foraging individuals (Smith et al. 2003; Weissburg 2005; Raine and Chittka 2007). For example, flower color appears to be correlated with energetic value, so that local variation in flower traits could drive selection for innate color biases in foraging 
bees (Raine and Chittka 2007). Raine and Chittka (2007) found that the colony with the strongest bias for violet-the flower color associated with the highest nectar production rates-brought in $41 \%$ more nectar than the colony with the weakest bias, implying that differences in foraging behavior are adaptive. The association between flower color and nectar profitability-specifically UV-blue flowers and high nectar contents-has been shown across years (Raine et al. 2006; Raine and Chittka 2007) as well as across several habitats (Giurfa et al. 1995; Chittka et al. 2004). As a result, the selective pressure favoring a UVblue preference appears to be strong but is limited, perhaps, by frequency-dependent selection, especially when a strong color bias by too many colonies will cause an over-exploitation of flowers with that color, thereby giving an advantage to colonies with alternative preferences (Raine and Chittka 2007). Because foraging and feeding strategies are likely to be driving forces in the evolution of many sensory systems, we need more studies integrating sensory and behavioral approaches to test these issues. At the interface of these two disciplines lies a promising avenue of research by which scientists will be able to quantify how levels of variation in sensory traits influence the performance of foraging animals and, subsequently, their overall fitness (see also Goerlitz and Siemers 2007; Greiner et al. 2007; Melin et al. 2007, 2008; Vogel et al. 2007).

\section{VARIABILITY BETWEEN DEVELOPMENTAL STAGES}

Ontogenetic studies may be useful in furthering our understanding of the evolutionary forces acting on sensory systems. Key ecological processes, such as resource use and predation risk, generally change with body size, and species, therefore, require commensurate adjustment of their sensory equipment as they grow (Werner and Gilliam 1984; Beaudet and Hawryshyn 1999; Jones 1999; Savchenko et al. 2001; Heming 2003). Several authors have tested the hypothesis that the timing and priority of changes in sensory system properties throughout development is linked to functional demands and ecological requirements (see Jaeger and Hailman 1976). For example, an ontogenetic shift in the spectral sensitivity and polarization of cone photoreceptors in juvenile teleost fish is associated with changes in either habitat or diet (Shand et al. 1988; Hawryshyn et al. 1990; Wood et al. 1992; Novales Flamarique 2000; Job and Shand 2001; Shand et al. 2008). Shand et al. (2008) showed that the black bream ( $A c$ anthopagrus butcheri) was able to respond to changes in environmental light by altering the opsin expression in its long wavelength-sensitive receptors, both during growth and in mature animals reared under laboratory conditions or caught in the wild (Figure 3). In crickets, the ontogeny of the air-flow sensory cercal structure is likely related to predation pressures. Not only does the sensitivity of the cercal system to sinusoidal signals increase as a result of the appearance of new air-flow sensitive hairs, but the value of the "best" tuned frequency also remains fixed between 150 and $180 \mathrm{~Hz}$ after the second life stage (Dangles et al. 2006c). These frequencies nicely match those emitted by natural flying predators, thus suggesting that the development of the cercal array of hairs may have evolved in response to such signals.

Although sensory variation among juveniles is frequently ignored, we believe that sensory ecologists should invest more energy in studying these systems (see also Adams and Pedersen 2000 for echolocation; Dangles et al. 2006b for flow sensing). Indeed, the impact of selection upon developmental variation is an important mechanism that produces phenotypic variation among adults, and selective pressures are likely to be greatest during early lifehistory stages, as, in many species, predation more strongly affects young individuals (McNamara 1997). It would also be interesting to study variation in the developmental rate of sensory systems as a function of ecological pressures (e.g., predation, habitat characteristics) experienced by organisms. Whereas few species 
possess a fully operational sensory system during their early life stages (e.g., electroreception in mormyrid fishes [Denizot et al. 1998], mechanoreception in crickets [Dangles et al. 2006c]), most have rudimentary sensory capabilities at birth that require sub-

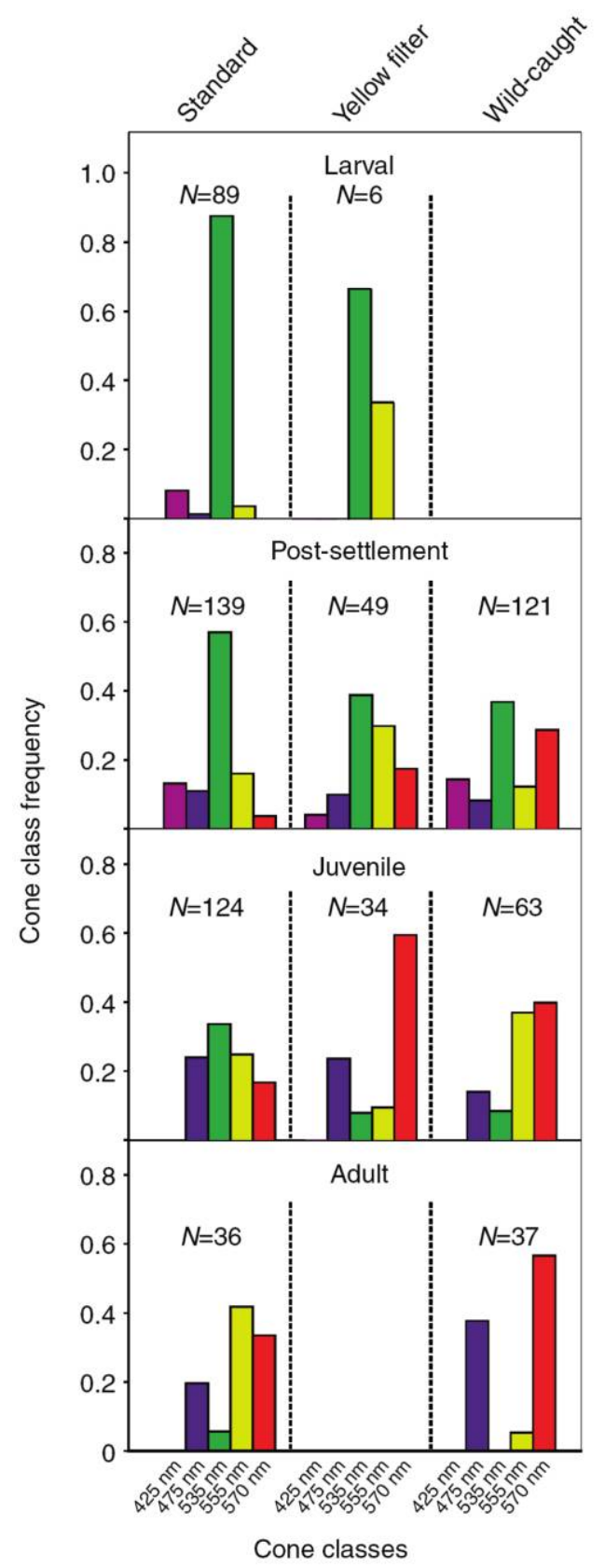

stantial development (e.g., audition in mammals [Rubel 1984], vision in fish [Higgs and Fuiman 1996], audition in insects [LakesHarlan and Strau $\beta$ 2006]). Functional requirements during the development of early life stages may act as constraints for the evolution of adult organs, and this remains an exciting but poorly explored field of sensory ecology (for an explicit discussion of the auditory system of cicadas, see Lakes-Harlan and Strau $\beta$ 2006).

\section{Future Challenges}

TAKING THE LAB TO THE FIELD

The need to quantify sensory performance of organisms in nature presents a major challenge for sensory ecologists. Fortunately, the last decade has witnessed an explosion of mobile and wireless technology that enables researchers to literally take the "laboratory into the field," and some sensory ecology research has already felt the advantage of these technological changes (e.g., vision research [Fleishman et al. 1998; Chiao et al. 2000; Warrant 2001; Endler and Day 2006; Jordão et al. 2007; Cummings et al. 2008], echolocation research [Triblehorn and Yager 2005; Holderied et al. 2005], audition research [Roemer and Bailey 1986; Narins et al. 2003], and flow sensor research [Barth et al. 1995; Dangles et al. 2007]). This potential distinc-

Figure 3. Eye Cone Class Frequency and the Developmental Stages of the Black Bream (ACANTHOPAGRUS BUTCHERI)

Frequency of eye cone classes were measured at different developmental stages in wild-caught black bream (Acanthopagrus butcheri) reared under two different lighting conditions. The first lighting condition was "standard," consisting of broad spectrum fluorescent lighting with an intensity at approximately $70 \mathrm{E} / \mathrm{cm}^{-2}, 400-700 \mathrm{~nm}$. The second lighting condition was produced through the use of a yellow acetate filter, thereby providing a reduced transmission of short wavelengths (short wavelength-reduced lighting is typical in estuarine conditions). Data from all four stages for fish reared under standard conditions are shown. No data were available for wildcaught larval fish or for adult yellow filter fish. (From Shand et al. 2008; reproduced with permission of the Company of Biologists.) 
tion between field and laboratory performance is not a trivial issue for sensory biologists, because many animals are difficult to study in natural settings while maintaining suitable experimental control. Animals often exhibit fundamentally different behaviors in the field compared to standardized laboratory environments. For example, laboratory studies on locomotion assume that the level of performance expressed under "optimal" conditions accurately reflects the level of performance used in nature, but this assumption is not always borne out (Irschick and Garland 2001; Irschick 2003).

More than twenty years ago, Römer's pioneering field work on cricket acoustic communication emphasized the importance of studying animals under natural stimulus conditions in order to properly investigate sensory system performance (Rheinlaender and Römer 1986; Römer and Bailey 1986; Römer and Lewald 1992). In particular, this research showed that the loss of sound signals outdoors, especially when insects call within stands of vegetation, has forced insects to compensate by adapting specific behaviors such as redundancy calls or chorusing. More recently, Dangles et al. (2007) used a portable simulator of spider air-flow signals to measure the sensory-mediated escape performance of crickets under field conditions (Figure 4A, B). This experiment revealed that both the behavior and performance of evading crickets in nature, as well as the sensory pathways involved in such escape behavior, differ in several ways from observed laboratory performance. A majority of crickets escaped running predators only after physical contact, and not by using their winddetection system as generally assumed in the literature (Figure 4C, D). Besides providing for the crucial role of cercal touch perception during cricket escapes, these results reinforced the importance of considering the issue of multimodality in sensory ecology studies based upon the fact that many animals use a hierarchy of cues (e.g., visual, odour, touch) to establish risk, and these cues may change over time, as animals learn to ignore irrelevant stimuli (e.g., Bell 1990; Hern et al. 1996; Dukas 1998; Rowe and
Guilford 1999; Cronin 2005; Conover 2007; Catania et al. 2008).

Engaging in sensory ecology fieldwork also forces us to devote our attention to so-called "background noise" in natural environments, as detection thresholds may often be so low that they are within the range of natural noise. Sensory processing in animals is shaped by the ubiquitous presence of background noise, requiring the separation of signal from noise (Dusenbery 1992). As a further step, the concept of stochastic resonance deals with the use of noise to increase the sensitivity of sensory systems (Osipov et al. 2007). For example, electrosensitive paddlefishes use stochastic resonance for homing in on Daphnia prey (Russell et al. 1999). Thus, the popular view of a passive external world in which organisms can easily sense one another is a simplification of a more complex reality. Field studies of both the intrinsic qualities of background noise and its interaction with organisms are therefore highly necessary. For instance, mate selection through vision or hearing in the "noisy" field environment may be quite different from that which occurs within quieter and more controlled laboratory settings (Gerhardt and Huber 2002). For animals sensing in the active mode, interference from conspecifics is reduced by rapid attenuation of the signals, spacing between conspecifics, and individual differences in the emitted signals that serve to avoid interference when in close proximity (the jamming avoidance response) (see Heiligenberg 1991). However, this background noise may present a problem for animals using active sensing systems, such as electrolocation or echolocation, as these systems may experience jamming from the signals of neighboring conspecifics. Most species of weakly electric fishes show a jamming avoidance response, achieved by adjusting the discharges of individuals, thus emphasizing differences between emissions in response to the signals of neighbors. For all of these reasons, we need more information on sensorymediated behavior (e.g., mate choice, predation) that takes into account both natural abiotic and biotic environmental conditions. 
INVESTIGATING BOTH VIEWPOINTS: SENDER AND RECEIVER

Because sensory systems are crucial for many interspecific interactions, the evolution of these systems and their variability in performance should be considered in a co-evolutionary context (see Searcy and Nowicki 2005; Bargmann 2006). Since a complete understanding of sensory ecology needs to take into consideration the sensory responses of potential prey, predators, and conspecifics, it is useful for sensory ecologists to establish differences among sensory signals when the interests of the two partners overlap, diverge, or oppose (Searcy and Nowicki 2005).

In the case of converging interests, Chittka and Menzel (1992) quantified the evolutionary "tuning" between floral coloration and the color vision of flower-visiting Hymenoptera by evaluating the information transfer from the signaling flower to the perceiving pollinator. The analysis of 180 reflection spectra of angiosperm blossoms revealed that sharp contrasts occur precisely at those wavelengths at which pollinators are most sensitive to spectral differences. Based on evolutionary theory (see Fordyce 2006), we can predict that adaptive evolution of sensory system phenotypes in response to recognition of food is favored when individuals within a population interact with a small array of signals. In case of opposing interests, such as predator-prey interactions, sensory systems have likely evolved in an environment presenting dynamic evolutionary interactions (e.g., an evolutionary arms race; see Endler 1991 for an explicit discussion). A classic example of the co-evolution of prey and predators within a sensory ecology context is the interaction between insectivorous bats and Arctiid moths (Roeder and Treat 1957; Fullard 1987; Hoy 1992; Miller and Surlykke 2001). While bats emit highintensity ultrasonic pulses and use echoes to locate and track flying prey, some Arctiid moths can direct ultrasonic clicks back at the echolocating bat. The function of these clicks remains unclear; they may serve either to warn the bat that the moth is distasteful (Spangler 1988) or to jam its echolocating system (Fullard et al. 1979), or perhaps both (Ratcliffe and Fullard 2005). In more general terms, the remarkable diversity in insect ears suggests that predator-prey interactions between bats and insects have played a key role in the evolution of insect auditory systems (Hoy and Robert 1996). Further studies incorporating bat acoustics and moth palatability and acoustics in a phylogenetic framework would be useful for refining evolutionary hypotheses in the moth-insect system (Barber and Conner 2006).

Much remains to be learned about the manner in which other sensory systems have co-evolved, and equal attention to both partners in sensory co-evolution is essential. By integrating the sensory ecology of both predator and prey, Dangles et al. (2006a) and Casas et al. (2008) have shown that the hunting strategies of wolf spiders are constrained by the air displacements these predators generate when running towards cricket prey. These authors argued that studying the role of signals produced by predators and perceived by prey sheds light on our understanding of foraging strategies typically studied in terms of energetics, biomechanics, or escape success rates (Casas et al. 2008). Understanding the sensory interplay between interacting species may also provide insights on broad patterns of sensory system evolution (see Robert et al. 1992 on the evolution of hearing in a parasitoid fly and its host). In this context, the asymmetry of predator-prey interactions may have important consequences for the evolution of sensory system performance. For example, viscous coupling between air-flow sensory hairs may be undesirable for predators (e.g., spiders) in the detection of their prey but desirable for prey (e.g., cockroaches) in the detection of their predators (Humphrey and Barth 2008). Whereas predators might need independent information from many hairs for proper target localization, prey might need to have many hairs moving simultaneously to trigger an efficient escape. Similarly, predator eyes are often adapted for high performance in specific directions, whereas prey visual systems seem better designed for detecting the 
presence of predators at almost any location (see Cronin 2005; Siemers and Güttinger 2006). The importance of asymmetry in the characteristics of sensory modalities used by interacting species therefore constitutes a promising field of research for sensory ecologists.
INVESTIGATING THE ADAPTIVE NATURE OF SENSORY SYSTEMS

Because sensory systems are not necessarily fixed entities, plasticity in these systems enables individuals to adapt to different environments (see Fleishman et al.
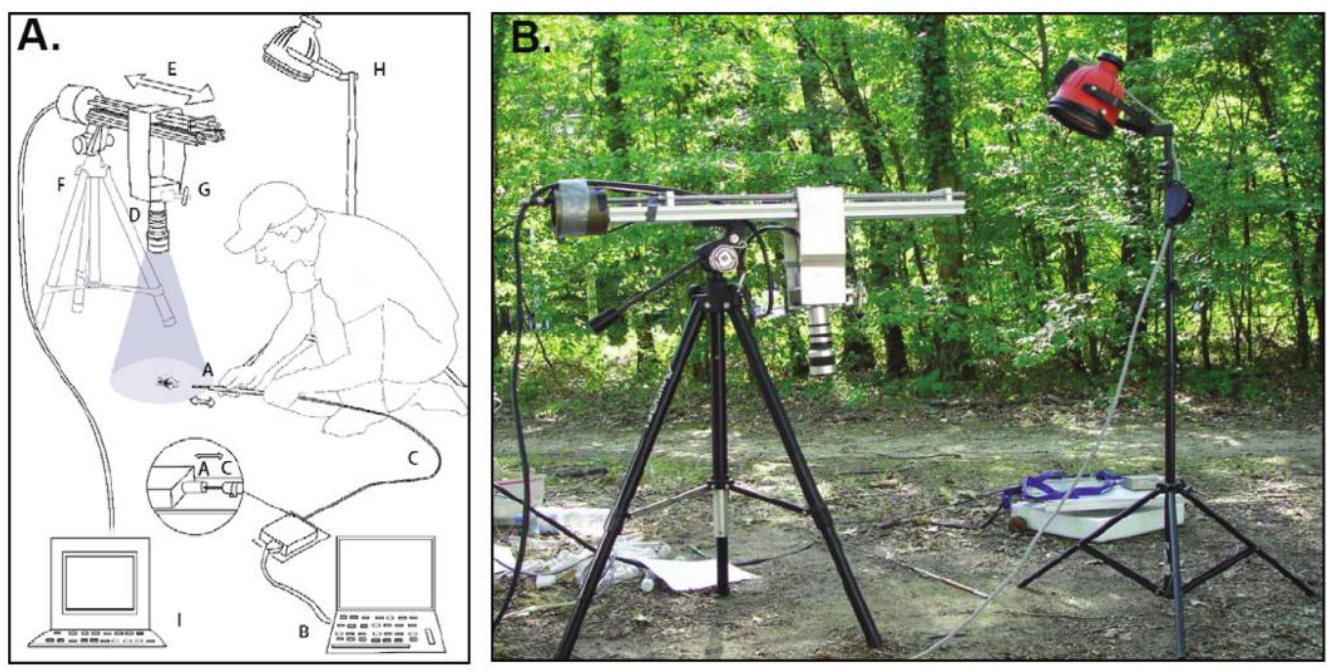

C.
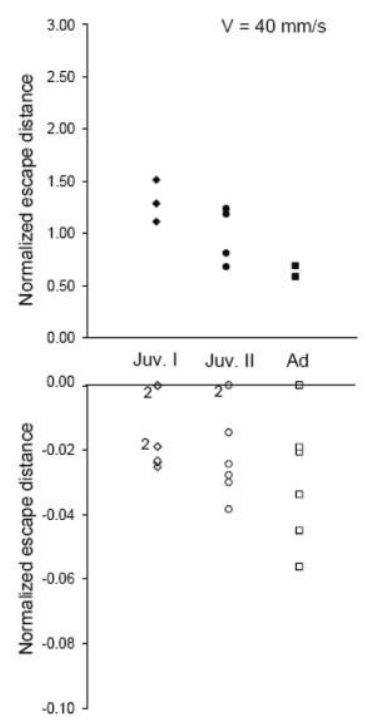
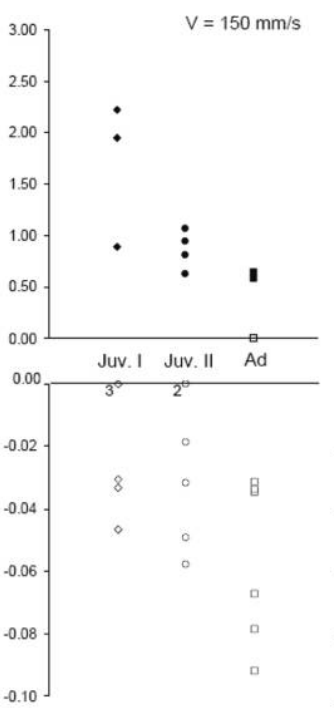

D.

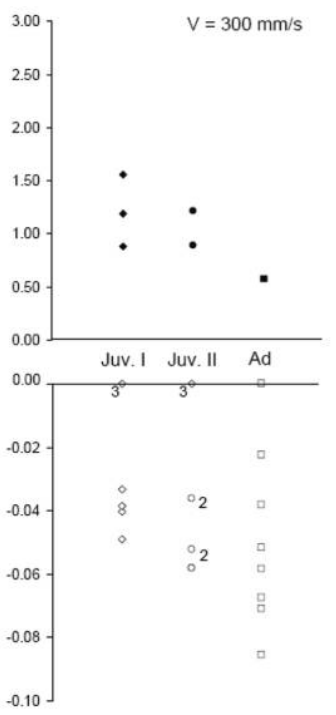

Figure 4 . 
1997; Wilczynski and Ryan 1999; Cronin et al. 2001; Boughman 2002; Leal and Fleishman 2002; Linkenhoker and Knudsen 2002; Doberfull et al. 2005). For example, in the mantis shrimp (Haptosquilla trispinosa), which occupies a range of depths in the ocean, the maximum spectral sensitivity of long-wavelength photoreceptors is adjusted by individuals to the local light environment, indicating a significant degree of plasticity in tailoring their visual systems to different habitats (Cronin et al. 2001). As pointed out earlier, many sensory systems are not fully developed at birth, and organisms have the capacity to make adjustments in neural connection patterns depending on environmental conditions. In the case of the mantis shrimp, Cronin et al. (2001) have experimentally demonstrated that the occurrence of different filter sets in adult populations was influenced by light conditions during development. In an evolutionary context, Frederiksen and Warrant (2008) have argued that the visual systems of invertebrates seem sufficiently flexible so as to evolve to be matched and optimized for a particular intensity window. At a species level, the spectral tuning of vertebrate visual pigments is also generally considered to be adaptive (Archer et al. 1999). Because environmental conditions are frequently highly variable, it is likely that developmental stages, populations, and species will exhibit a high level of plasticity in a wide variety of sensory modalities, but further study will determine the generality of this hypothesis.

The magnitude of plasticity in sensory systems has important evolutionary implications, as plastic sensory systems may facilitate fluctuating selection and reduce the potential for divergence among populations (Lande 1981). We believe that sensory ecologists should devote more effort toward investigating the adaptive nature of sensory systems in populations living in different environments. This would inject new energy into our understanding of both the relative amounts of genetic and/or environmental variation in sensory system properties (see Fuller et al. 2005; Lavagnino et al. 2008) as well as the occurrence of individual adaptation, or short-term physiological receptor adaptation. To achieve these goals, sensory ecologists can borrow tools

\section{Figure 4. Flow-Mediated Escape Performance of Wood Crickets (Orthoptera) Measured Under Field Conditions}

A drawing (A) and photograph (B) of the portable equipment used to measure the flow-mediated escape performance of freely behaving wood crickets (Nemobius sylvestris) taken from wild populations, under the natural conditions (i.e., leaf litter substrate, slow breeze, natural acoustic environment, temperature and humidity conditions) of a European oak forest. The use of a halogen lamp, which was necessary for our high-speed camera recordings, supplied an artificial light environment. To simulate a spider attack, a "spider operator" used an original device activated by the displacement of an actuator-triggered "piston" (A, part A) (see Dangles et al. 2006b) and controlled by a portable computer (A, part B). The use of the piston in the field was facilitated by a $1.5 \mathrm{~m}$ wire (A, part $\mathrm{C}$ ) that ran between the actuator and the tip of the piston. Cricket escape behavior was recorded using a high-speed digital video camera (A, part D) with a frame rate of 1000 frames per second and resolution of $1280 \times 512$ pixels. The camera was mounted on a $\operatorname{ramp}(\mathrm{A}$, part E) fixed on the rotating head of a stable tripod $0.5 \mathrm{~m}$ above the ground (A, part F). A red laser pointer (A, part $\mathrm{G}$ ) was focused on the cricket body and enabled us to center the cricket in the camera's field of vision. The ground was illuminated by a halogen lamp (A, part $\mathrm{H}$ ), and the video acquisition was controlled using a laptop (A, part I). (C) Escape distances normalized to total body length of wood crickets for three different instars-juvenile I (Juv. 1), juvenile II (Juv. 2), and adults (Ad.) —at three piston velocities (40 mm/s, $150 \mathrm{~mm} / \mathrm{s}$ and $300 \mathrm{~mm} / \mathrm{s}$ ). Numbers indicate two or three crickets escaping at similar distance values. Data for air-evoked escapes are presented in the top row of graphs, and data for touch-evoked escapes are presented in the bottom row. Note that the range of values displayed in the touch-evoked graphs is of a lower magnitude than the range displayed in the air-evoked graphs. (D) The tip of the cricket's cerci lines up with the x-axis. An escape distance of zero corresponds to the tip of the cerci being touched by the piston. Bold arrows represent the direction of piston movement. Positive and negative values of escape distances correspond to air- and touch-evoked responses, respectively. (Figure from Dangles et al. 2007; reproduced with permission of the Company of Biologists.) 
from evolutionary biologists, such as reciprocal transplant experiments, in which individuals from populations from two or more environments are each introduced into the other's environment(s) (e.g., Reznick et al. 1990; Endler et al. 2001; Chittka et al. 2004). This would allow scientists to compare the sensory performance of native organisms with those arising from populations operating in different environments, and to thereby determine whether variation is attributable to genetics, environment, or the interaction between them (see Fuller et al. 2005; Raine et al. 2006). Preferably, the potential adaptation in sensory performance within relevant temporal and spatial scales for species should be studied (e.g., Cronin and Shashar 2001; Fuller et al. 2003; Beckers and Schul 2008), as environmental factors in both natural and disturbed ecosystems are often stochastic.

\section{SENSORY ECOLOGY IN A CHANGING WORLD}

Recent reviews have stressed that, in the context of a dramatically changing world, rapid evolution may become a hallmark of the 21st century (Carroll et al. 2007). At first glance, sensory biologists may think that such changes are unlikely to affect their study organisms, yet we argue that this is far from true (see also Endler 1997; Rabin et al. 2003; Lim et al. 2008). In order to survive, animal populations may have to undergo morphological and functional adaptations to cope with rapidly changing conditions, and sensory systems may be a key source of increasing variability. We argue that understanding sensory mechanisms maybe a useful starting point for a variety of practical ecological applications (see Weissburg 2005), and we provide some examples of these as follows.

One of the most dramatic examples of human impact on species sensory ecology may be the case of sympatric Cichlid fish species in the Great Lakes of Africa. Increases in water turbidity due to eutrophication threaten the reproductive isolation of these species, which is usually maintained via mate choice based on the bright species-specific coloration of males (Seehausen et al. 1997; Salzburger et al. 2006).
In Lake Victoria, light quality has declined to the point where female choice is compromised as a result of changes in the spectral composition of male nuptial coloration. Males are becoming increasingly dullcolored, and species diversity in areas of recent eutrophication is more related to light availability than to any other anthropogenic stressor. More generally, any change in illumination and turbidity is of serious concern in many aquatic environments (including coral reefs) and has potential consequences for vision-mediated activities such as predation or mating (Johnsen 2005). Light pollution also affects the sensory ecology of terrestrial species, with consequences for foraging, reproduction, migration, and communication (see Longcore and Rich 2004). Some of the first selection experiments ever conducted were performed on Drosophila phototaxis (del Solar 1966), and these showed strong genetic effects in relatively few generations, thus indicating that there might be a genetic scope for coping with light pollution.

Sensory modalities other than vision, such as olfaction or audition, may be affected in ecosystems where natural physical properties are modified by human activities. Fish olfaction, for example, is altered by water chemical pollution (e.g., Bertmar 1982; Hansen et al. 1999), with potential impacts on natural water discrimination along chemical gradients, such as salinity or home stream odor (Hubbard et al. 2000), or social recognition (Ward et al. 2008). There is also concern that increasing noise levels in the oceans (produced by sonars and shipping, for example) confuse the acoustic signals that cetaceans and other aquatic organisms use to navigate, communicate, and locate food (e.g., Richardson et al. 1998; Frantzis 1998; Doak et al. 2007). Ross (1987) has estimated that increases in ship traffic over the past fifty years have led to a $15 \mathrm{~dB}$ increase in ambient noise levels in the low-frequency bands used by many marine mammals. Although our knowledge on lethal and sublethal effects of anthropogenic sound on animals in the wild remains poor (Gisiner 
1998), it is likely that increasingly noisy habitats will have significant effects on both terrestrial and aquatic organisms (Klump 1996; Rabin and Greene 2002; Sun and Narins 2005; Schaub et al. 2008). Animals have the ability to discriminate among various types of natural background noise (both auditory [Brumm and Slabbekoorn 2005] and visual [Ord et al. 2007]), but the ecological and evolutionary adaptations of populations and species living in increasingly noisy habitats remain poorly known (see Slabbekoorn and Ripmeester 2008 for a discussion on the effects of anthropogenic noise on birdsong) and constitute a promising area of research for both sensory and conservation ecologists.

\section{Conclusion}

In this review, we have attempted to demonstrate that sensory systems are not only amenable to an integrative approach at different levels of variability, but also that this integrative approach is crucial for advancing the field of sensory ecology. The complementary nature of studies on the variation in structure and function of sensory systems allows a more complete understanding of the sensory-mediated interactions that occur between organisms and the evolutionary forces acting upon them. Many taxonomic groups present spectacular diversity in the arrangement, number, or size of their sensory structures, but the causes and consequences of this variation remain largely unexplored. The investigation of variation in the performance of sensory systems among species, populations, and developmental stages, especially under natural conditions, represents a promising field of research that may serve not only to refine our understanding of the past evolution of sensory systems, but also to predict how animal behavior and sensory capabilities will continue to adapt to a changing world.

\section{ACKNOWLEDGMENTS}

The authors warmly thank James D. Thomson and two anonymous reviewers who provided insightful comments on a previous version of the manuscript.

\section{REFERENCES}

Adams R. A., Pedersen S. C. 2000. Integrating ontogeny into ecological and evolutionary investigations. Pages 1-8 in Ontogeny, Functional Ecology, and Evolution of Bats, edited by R. A. Adams and S. C. Pedersen. Cambridge (UK): Cambridge University Press.

Ali M. A., editor. 1978. Sensory Ecology. New York: Plenum Press.

Alves-Gomes J. A. 2001. The evolution of electroreception and bioelectrogenesis in teleost fish: a phylogenetic perspective. Journal of Fish Biology 58 : 1489-1511.

Anderbrant O., Löfqvist J., Högberg H.-E., Hedenström E., Badassari N., Baronio P., Kolmakova G., et al. 2000. Geographic variation in the field response of male European pine sawflies, Neodiprion sertifer, to different pheromone stereoisomers and esters. Entomologia Experimentalis et Applicata 95(3): 229-239.

Archer S. N., Djamgoz M. B. A., Loew E. R., Partridge J. C., Valerga S., editors. 1999. Adaptive Mechanisms in the Ecology of Vision. Dordrecht (The Netherlands): Kluwer Academic.

Archer S. N., Endler J. A., Lythgoe J. N., Partridge J. C. 1987. Visual pigment polymorphism in the guppy Poecilia reticulata. Vision Research 27(8):1243-1252.
Arnegard M. E., Carlson B. A. 2005. Electric organ discharge patterns during group hunting by a mormyrid fish. Proceedings of the Royal Society of London, Series B: Biological Sciences 272(1570):13051314.

Arnold S. J. 1983. Morphology, performance and fitness. American Zoologist 23(2):347-361.

Avila C., Taboadal S., Núñez-Pons L. 2008 Antarctic marine chemical ecology: what is next? Marine Ecology 29(1):1-71.

Barber J. R., Conner W. E. 2006. Tiger moth responses to a simulated bat attack: timing and duty cycle. Journal of Experimental Biology 209(14):26372650.

Bargmann C. I. 2006. Comparative chemosensation from receptors to ecology. Nature 444(7117):295301.

Barlow H. B., Mollon J. D., editors. 1982. The Senses. Cambridge (UK): Cambridge University Press.

Barth F. G. 2002. A Spider's World: Senses and Behavior. Berlin (Germany): Springer.

Barth F. G., Humphrey J. A. C., Wastl U., Halbritter J., Brittinger W. 1995. Dynamics of arthropod filiform hairs. III. Flow patterns related to air movement detection in a spider (Cupiennius salei Keys). 
Philosophical Transactions of the Royal Society of London, Series B: Biological Sciences 347(1322):397-412.

Barth F. G., Schmid A., editors. 2001. Ecology of Sensing. Berlin (Germany): Springer.

Baugh A. T., Akre K. L., Ryan M. J. 2008. Categorical perception of a natural, multivariate signal: mating call recognition in túngara frogs. Proceedings of the National Academy of Sciences USA 105(26):89858988.

Beaudet L., Hawryshyn C. W. 1999. Ecological aspects of vertebrate visual ontogeny. Pages 413-437 in Adaptive Mechanisms in the Ecology of Vision, edited by S. N. Archer et al. Dordrecht (The Netherlands): Kluwer Academic.

Beckers O. M., Schul J. 2008. Developmental plasticity of mating calls enables acoustic communication in diverse environments. Proceedings of the Royal Society of London, Series B: Biological Sciences 275(1640): 1243-1248.

Bell W. J. 1990. Searching behavior patterns in insects. Annual Review of Entomology 35:447-467.

Bell W. J., Cardé R., editors. 1984. Chemical Ecology of Insects. Sunderland (MA): Sinauer Associates.

Bernardi G., Bucciarelli G. 1999. Molecular phylogeny and speciation of the surfperches (Embiotocidae, Perciformes). Molecular Phylogeny and Evolution 13(1):77-81.

Bernays E. A., Wcislo W. 1994. Sensory capabilities, information processing, and resource specialization. Quarterly Review of Biology 69(2):187-204.

Bertmar G. 1982. Structure and function of the olfactory mucosa of migrating Baltic trout under environmental stresses, with special reference to water pollution. Pages 395-422 in Chemoreception in Fishes, Develop ments in Aquaculture and Fisheries Science, Volume 8, edited by T. J. Hara. Amsterdam (The Netherlands): Elsevier, Scientific Publishing Company.

Biro D., Freeman R., Meade J., Roberts S., Guilford T. 2007. Pigeons combine compass and landmark guidance in familiar route navigation. Proceedings of the National Academy of Sciences USA 104(18): 7471-7476.

Boughman J. W. 2002. How sensory drive can promote speciation. Trends in Ecology and Evolution 17(12):571-577.

Boul K. E., Ryan M. J. 2004. Population variation of complex advertisement calls in Physalaemus petersi and comparative laryngeal morphology. Copeia 2004(3):624-631.

Bowmaker J. K. 1983. Trichromatic colour vision: why only three receptor channels? Trends in Neurosciences 6:41-43.

Bowmaker J. K., Govardovskii V. I., Shukolyukov S. A., Zueva L. V., Hunt D. M., Sideleva V. G., Smirnova O. G. 1994. Visual pigments and the photic environment: the cottoid fish of Lake Baikal. Vision Research 34(5):591-605.
Bowmaker J. K., Hunt D. M. 2006. Evolution of vertebrate visual pigments. Current Biology 16(13): R484-R489.

Bradbury J. W., Vehrencamp S. L. 1998. Principles of Animal Communication. Sunderland (MA): Sinauer.

Briscoe A. D. 1998. Molecular diversity of visual pigments in the butterfly Papilio glaucus. Naturwissenschaften 85(1):33-35.

Briscoe A. D. 2008. Reconstructing the ancestral butterfly eye: focus on the opsins. Journal of Experimental Biology 211(11):1805-1813.

Briscoe A. D., Chittka L. 2001. The evolution of color vision in insects. Annual Review of Entomology 46: 471-510.

Browman H. I., Hawryshyn C. W., editors. 2001. Biology of ultraviolet and polarization vision. Journal of Experimental Biology 204(14):2383-2596.

Brumm H., Slabbekoorn H. 2005. Acoustic communication in noise. Advances in the Study of Behavior 35:151-209.

Bullock T. H., Hopkins C. D., Popper A. N., Fay R., editors. 2005. Electroreception. New York: Springer.

Buskey E. J., Hartline D. K. 2003. High-speed video analysis of the escape responses of the copepod Acartia tonsa to shadows. Biological Bulletin 204(1): 28-37.

Cardé R. T., Millar J. G. 2004. Advances in Insect Chemical Ecology. Cambridge (UK): Cambridge University Press.

Carroll S. P., Hendry A. P., Reznick D. N., Fox C. W. 2007. Evolution on ecological time-scales. Functional Ecology 21 (3):387-393.

Casas J., Steinmann T., Dangles O. 2008. The aerodynamics of hunting spiders. PLoS ONE 3:e2116.

Catania K. C., Hare J. F., Campbell K. L. 2008. Water shrews detect movement, shape, and smell to find prey underwater. Proceedings of the National Academy of Sciences USA 105(2):571-576.

Chapman R. F., Lee J. C. 1991. Environmental effects on numbers of peripheral chemoreceptors on the antennae of a grasshopper. Chemical Senses 16(6): 607-616.

Chiao C.-C., Cronin T. W., Osorio D. 2000. Color signals in natural scenes: characteristics of reflectance spectra and effects of natural illuminants. Journal of the Optical Society of America A: Optics, Image Science, and Vision 17(2):218-224.

Chittka L. 1996a. Optimal sets of colour receptors and colour opponent systems for coding of natural objects in insect vision. Journal of Theoretical Biology 181(2):179-196.

Chittka L. 1996b. Does bee color vision predate the evolution of flower color? Naturwissenschaften 83(3): 136-138.

Chittka L., Briscoe A. 2001. Why sensory ecology needs to become more evolutionary-insect color vision as a case in point. Pages 19-38 in Ecology of 
Sensing, edited by F. G. Barth and A. Schmid. Berlin (Germany): Springer.

Chittka L., Ings T. C., Raine N. E. 2004. Chance and adaptation in the evolution of island bumblebee behaviour. Population Ecology 46:243-251.

Chittka L., Menzel R. 1992. The evolutionary adaptation of flower colours and the insect pollinators' colour vision systems. Journal of Comparative Physiology A: Neuroethology, Sensory, Neural, and Behavioral Physiology 171(2):171-181.

Chittka L., Spaethe J., Schmidt A., Hickelsberger A. 2001. Adaptation, constraint, and chance in the evolution of flower color and pollinator color vision. Pages 106-126 in Cognitive Ecology of Pollination, edited by L. Chittka and J. D. Thomson. Cambridge (UK): Cambridge University Press.

Chittka L., Thomson J. D., editors. 2001. Cognitive Ecology of Pollination: Animal Behavior and Floral Evolution. Cambridge (UK): Cambridge University Press.

Conover M. R. 2007. Predator-Prey Dynamics: The Role of Olfaction. Boca Raton (FL): CRC Press.

Cronin T. W. 2005. The visual ecology of predatorprey interactions. Pages 105-138 in Ecology of Predator-Prey Interactions, edited by P. Barbosa and I. Castellanos. New York: Oxford University Press.

Cronin T. W. 2006. Invertebrate vision in water. Pages 211-249 in Invertebrate Vision, edited by E. Warrant and D. E. Nilsson. Cambridge (UK): Cambridge University Press.

Cronin T. W., Caldwell R. L., Erdmann M. V. 2002. Tuning of photoreceptor function in three mantis shrimp species that inhabit a range of depths. I. Visual pigments. Journal of Comparative Physiology A: Neuroethology, Sensory, Neural, and Behavioral Physiology 188(2):179-186.

Cronin T. W., Caldwell R. L., Marshall J. 2001. Sensory adaptation: tunable colour vision in a mantis shrimp. Nature 411(6837):547-548.

Cronin T. W., Shashar N. 2001. The linearly polarized light field in clear, tropical marine waters: spatial and temporal variation of light intensity, degree of polarization and e-vector angle. Journal of Experimental Biology 204(14):2461-2467.

Cummings M. E. 2007. Sensory trade-offs predict signal divergence in surfperch. Evolution 61(3):530545 .

Cummings M. E., Jordão J. M., Cronin T. W., Oliveira R. F. 2008. Visual ecology of the fiddler crab, Uca tangeri: effects of sex, viewer and background on conspicuousness. Animal Behaviour 75(1):175-188.

Dacke M., Nilsson D.-E., Scholtz C. H., Byrne M., Warrant E. J. 2003. Insect orientation to polarized moonlight. Nature 424(6944):33.

Dangles O., Casas J., Coolen I. 2006b. Textbook cricket goes to the field: the ecological scene of the neuroethological play. Journal of Experimental Biology 209(3):393-398.

Dangles O., Magal C., Pierre D., Olivier A., Casas J. 2005. Variation in morphology and performance of predator-sensing system in wild cricket populations. Journal of Experimental Biology 208(3):461468.

Dangles O., Ory N., Steinmann T., Christides J.-P., Casas J. 2006a. Spider's attack versus cricket's escape, velocity modes determine success. Animal Behaviour 72(3):603-610.

Dangles O., Pierre D., Christides J. P., Casas J. 2007. Escape performance decreases during ontogeny in wild crickets. Journal of Experimental Biology 210(18):3165-3170.

Dangles O., Pierre D., Magal C., Vannier F., Casas J. 2006c. Ontogeny of air-motion sensing in cricket. Journal of Experimental Biology 209(21):4363-4370.

del Solar E. 1966. Sexual isolation caused by selection for positive and negative phototaxis and geotaxis in Drosophila pseudoobscura. Proceedings of the National Academy of Sciences USA 56(2):484-487.

Denizot J.-P., Kirschbaum F., Schugardt C., Bensouilah M. 1998. Larval electroreceptors indicate a larval electric system in mormyrids. Neuroscience Letters 241 (2-3):103-106.

Devarakonda R., Barth F. G., Humphrey J. A. C. 1996. Dynamics of arthropod filiform hairs. IV. Hair motion in air and water. Philosophical Transactions of the Royal Society of London, Series B: Biological Sciences 351 (1342):933-946.

Dicke M., Grostal P. 2001. Chemical detection of natural enemies by arthropods: an ecological perspective. Annual Review of Ecology and Systematics 32:1-23.

Dicke M., Takken W., editors. 2006. Chemical Ecology: From Gene to Ecosystem. Dordrecht (The Netherlands): Springer.

Doak D., Bakker V., Finkelstein M., Sullivan B., Lewison R., Keitt B., Arnold J., Croxall J., Micheli F., Sanjayan M. 2007. Compensatory mitigation for marine bycatch will do harm, not good. Frontiers in Ecology and the Environment 5(7):350-351.

Dobberfuhl A. P., Ullmann J. F. P., Shumway C. A. 2005. Visual acuity, environmental complexity, and social organization in African cichlid fishes. Behavioral Neuroscience 119(6):1648-1655.

Dominy N. J., Lucas P. W., Osorio D., Yamashita N. 2001. The sensory ecology of primate food perception. Evolutionary Anthropology 10(5):171-186.

Douglas J. M., Cronin T. W., Chiou T. H., Dominy N. J. 2007. Light habitats and the role of polarized iridescence in the sensory ecology of neotropical nymphalid butterflies (Lepidoptera: Nymphalidae). Journal of Experimental Biology 210(5):788-799.

Dukas R., editor. 1998. Cognitive Ecology: The Evolution- 
ary Ecology of Information Processing and Decision Making. Chicago (IL): University of Chicago Press.

Dusenbery D. B. 1992. Sensory Ecology: How Organisms Acquire and Respond to Information. New York: W. H. Freeman.

Duvall D., Muller-Schwarze D., Silverstein R. M., editors. 1986. Chemical Signals in Vertebrates 4: Ecology, Evolution, and Comparative Biology. New York: Plenum Press.

Eckert M. P., Zeil J. 2001. Towards an ecology of motion vision. Pages 333-369 in Motion Vision: Computational, Neural and Ecological Constraints, edited by J. M. Zanker and J. Zeil. Berlin (Germany): Springer.

Eisner T., Meinwald M. J., editors. 1995. Chemical Ecology: The Chemistry of Biotic Interaction. Washington (DC): National Academies Press.

Endler J. A. 1991. Variation in the appearance of guppy color patterns to guppies and their predators under different visual conditions. Vision Research 31 (3):587-608.

Endler J. A. 1992a. Signals, signal conditions, and the direction of evolution. American Naturalist 139(supplement):s125-s153.

Endler J. A., editor. 1992b. Sensory drive: does sensory biology bias or constrain the direction of evolution? American Naturalist 139(supplement): s1-s153.

Endler J. A. 1997. Light, behavior and conservation of forest-dwelling organisms. Pages 330-356 in $\mathrm{Be}$ havioral Approaches to Conservation in the Wild, edited by J. R. Clemmons and R. Buchholz. Cambridge (UK): Cambridge University Press.

Endler J. A., Basolo A. L. 1998. Sensory ecology, receiver biases and sexual selection. Trends in Ecology and Evolution 13(10):415-420.

Endler J. A., Basolo A. L.., Glowacki S., Zerr J. 2001. Variation in response to artificial selection for light sensitivity in guppies (Poecilia reticulata). American Naturalist 158(1):36-48.

Endler J. A., Day L. B. 2006. Ornament colour selection, visual contrast and the shape of colour preference functions in great bowerbirds, Chlamydera nuchalis. Animal Behaviour 72(6):1405-1416.

Fields D. M., Weissburg M. J. 2005. Evolutionary and ecological significance of mechanosensor morphology: copepods as a model system. Marine Ecology Progress Series 287:269-274.

Fleishman L. J., Bowman M., Saunders D., Miller W. E., Rury M. J., Loew E. R. 1997. The visual ecology of Puerto Rican anoline lizards: habitat light and spectral sensitivity. Journal of Comparative Physiology A: Neuroethology, Sensory, Neural, and Behavioral Physiology 181(5):446-460.

Fleishman L. J., McClintock W. J., D’Eath R. B., Brainard D. H., Endler J. A. 1998. Colour perception and the use of video playback experiments in animal behaviour. Animal Behaviour 56(4):1035-1040.

Fordyce J. A. 2006. The evolutionary consequences of ecological interactions mediated through phenotypic plasticity. Journal of Experimental Biology 209(12):2377-2383.

Frantzis A. 1998. Does acoustic testing strand whales? Nature 392(6671):29.

Frederiksen R., Warrant E. J. 2008. Visual sensitivity in the crepuscular owl butterfly Caligo memnon and the diurnal blue morpho Morpho peleides: a clue to explain the evolution of nocturnal apposition eyes? Journal of Experimental Biology 211(6):844851.

Frentiu F. D., Bernard G. D., Cuevas C. I., SisonMangus M. P., Prudic K. L., Briscoe A. D. 2007. Adaptive evolution of color vision as seen through the eyes of butterflies. Proceedings of the National Academy of Sciences USA 104(supplement 1):86348640.

Fullard J. H. 1987. Sensory ecology and neuroethology of moths and bats: interactions in a global perspective. Pages 244-272 in Recent Advances in the Study of Bats, edited by M. B. Fenton et al. Cambridge (UK): Cambridge University Press.

Fullard J. H., Fenton M. B., Simmons J. A. 1979. Jamming bat echolocation: the clicks of arctiid moths. Canadian Journal of Zoology 57:647-649.

Fullard J. H., Yack J. E. 1993. The evolutionary biology of insect hearing. Trends in Ecology and Evolution $8(7): 248-252$.

Fuller R. C., Carleton K. L., Fadool J. M., Spady T. C., Travis J. 2005. Genetic and environmental variation in the visual properties of bluefin killifish, Lucania goodie. Journal of Evolutionary Biology 18(3): 516-523.

Fuller R. C., Fleishman L. J., Leal M., Travis J., Loew E. 2003. Intraspecific variation in retinal cone distribution in the bluefin killifish, Lucania goodei. Journal of Comparative Physiology A: Neuroethology, Sensory, Neural, and Behavioral Physiology 189(8): 609-616.

Gardiner A., Barker D., Butlin R. K., Jordan W. C., Ritchie M. G. 2008. Drosophila chemoreceptor gene evolution: selection, specialization and genome size. Molecular Ecology 17(7):1648-1657.

Gerhardt H. C. 2005. Acoustic spectral preferences in two cryptic species of grey treefrogs: implications for mate choice and sensory mechanisms. Animal Behaviour 70(1):39-48.

Gerhardt H. C., Huber F. 2002. Acoustic Communication in Insects and Anurans: Common Problems and Diverse Solutions. Chicago (IL): University of Chicago Press.

Gisiner R. C., editor. 1998. Effects of anthropogenic sounds on the hearing of marine mammals. Pages 19-49 in Proceedings of the Workshop on the Effects of 
Anthropogenic Noise in the Marine Environment, 10-12 February 1998, edited by R. C. Gisiner. Arlington (VA): Office of Naval Rearch.

Giurfa M., Núñez J., Chittka L., Menzel R. 1995. Colour preferences of flower-naive honeybees. Jour nal of Comparative Physiology A: Neuroethology, Sensory, Neural, and Behavioral Physiology 177(3):247259.

Goerlitz H. R., Siemers B. M. 2007. Sensory ecology of prey rustling sounds: acoustical features and their classification by wild grey mouse lemurs. Functional Ecology 21 (1):143-153.

Greenfield M. D. 2002. Signalers and Receivers: Mechanisms and Evolution of Arthropod Communication. Oxford (UK): Oxford University Press.

Greiner B., Narendra A., Reid S., Dacke M., Ribi W. A., Zeil J. 2007. Eye structure correlates with distinct foraging-bout timing in primitive ants. Current Biology 17(20):R879-R880.

Guillén A., Juste B. J., Ibáñez C. 2000. Variation in the frequency of the echolocation calls of Hipposideros ruber in the Gulf of Guinea: an exploration of the adaptive meaning of the constant frequency value in rhinolophoid CF bats. Journal of Evolutionary Biology 13(1):70-80.

Gustafsson O. S. E., Collin S. P., Kröger R. H. H. 2008. Early evolution of multifocal optics for wellfocused colour vision in vertebrates. Journal of $E x$ perimental Biology 211(10):1559-1564.

Hansen J. A., Rose J. D., Jenkins R. A., Gerow K. G., Bergman H. L. 1999. Chinook salmon (Oncorhynchus tshawytscha) and rainbow trout (Oncorhynchus mykiss) exposed to copper: neurophysiological and histological effects on the olfactory system. Environmental Toxicology and Chemistry 18(9):19791991.

Hansson B. S., Tóth M., Löfstedt C., Szöcs G., Subchev M., Löfqvist J. 1990. Pheromone variation among eastern European and a western Asian population of the turnip moth Agrotis segetum. Journal of Chemical Ecology 16(5):1611-1622.

Hart N. S. 2001a. The visual ecology of avian photoreceptors. Progress in Retinal and Eye Research 20(5): 675-703.

Hart N. S. 2001b. Variations in cone photoreceptor abundance and the visual ecology of birds. Journal of Comparative Physiology A: Neuroethology, Sensory, Neural, and Behavioral Physiology 187:685-698.

Hawryshyn C. W., Arnold M. G., Bowering E., Cole R. L. 1990. Spatial orientation of rainbow trout to plane-polarized light: the ontogeny of E-vector discrimination and spectral sensitivity characteristics. Journal of Comparative Physiology A: Neuroethology, Sensory, Neural, and Behavioral Physiology 166(4): 565-574.

Hay M. E., Fenical W. 1988. Marine plant-herbivore interactions: the ecology of chemical defense. Annual Review of Ecology and Systematics. 19:111-145.

Heiligenberg W. 1991 Neural Nets in Electric Fish. Cambridge (MA): MIT Press.

Heming B. S. 2003. Insect Evolution and Development. New York: Cornell University Press.

Hern A., Edwards-Jones G., McKinlay R. G. 1996. A review of the pre-oviposition behavior of the small cabbage white butterfly, Pieris rapae (Lepidoptera: Pieridae). Annals of Applied Biology 128(2):349371.

Higgs D. M., Fuiman L. A. 1996. Ontogeny of visual and mechanosensory structure and function in Atlantic menhaden Brevoortia tyrannus. Journal of Experimental Biology 199(12):2619-2629.

Holderied M. W., Korine C., Fenton M. B., Parsons S., Robson S., Jones G. 2005. Echolocation call intensity in the aerial hawking bat Eptesicus bottae (Vespertilionidae) studied using stereo videogrammetry. Journal the Experimental Biology 208(7):13211327.

Hoy R. R. 1992. The evolution of hearing in insects as an adaptation to predation from bats. Pages 115129 in The Evolutionary Biology of Hearing, edited by D. B. Webster et al. New York: Springer.

Hoy R. R., Robert D. 1996. Tympanal hearing in insects. Annual Review of Entomology 41:433-450.

Hubbard P. C., Barata E. N., Canario A. V. M. 2000. Olfactory sensitivity to changes in environmental [Ca2+] in the marine teleost Sparus aurata. Journal of Experimental Biology 203(24):3821-3829.

Hueter R. E. 1991. Adaptation for spatial vision in sharks. Journal of Experimental Zoology 5(supplement):130-141.

Humphrey J. A. C., Barth F. G. 2008. Medium flowsensing hairs: biomechanics and models. Pages 1-80 in Insect Mechanics and Control, Volume 34: Advances in Insect Physiology, edited by J. Casas and S. J. Simpson. London (UK): Academic Press.

Humphrey J. A. C., Barth F. G., Voss K. 2001. The motion-sensing hairs of arthropods: using physics to understand sensory ecology and adaptive evolution. Pages 105-115 in Ecology of Sensing, edited by F. G. Barth and A. Schmid. Berlin (Germany): Springer.

Humphrey J. A. C., Devarakonda R., Iglesias I., Barth F. G. 1993. Dynamics of arthropod filiform hairs. I. Mathematical modelling of the hair and air motions. Philosophical Transactions of the Royal Society of London, Series B: Biological Sciences 340 (1294): 423-444.

Irschick D. J. 2003. Measuring performance in nature: implications for studies of fitness within populations. Integrative Comparative Biology 43(3):396-407.

Irschick D. J., Dyer L., Sherry T. 2005. Phylogenetic methodologies for studying specialization. Oikos $110(2): 404-408$. 
Irschick D. J., Garland T., Jr. 2001. Integrating function and ecology in studies of adaptation: investigations of locomotor capacity as a model system. Annual Reviews of Ecology and Systematics 32:367396.

Jaeger R. G., Hailman J. P. 1976. Ontogenetic shift of spectral phototactic preferences in anuran tadpoles. Journal of Comparative Physiology and Psychology 90:930-945.

Job S. D., Shand J. 2001. Spectral sensitivity of larval and juvenile coral reef fishes: implications for feeding in a variable light environment. Marine Ecology Progress Series 214:267-277.

Johnsen S. 2005. Visual ecology on the high seas. Marine Ecology Progress Series 287:281-285.

Johnsen S. 2007. Does new technology inspire new directions? Examples drawn from pelagic visual ecology. Integrative and Comparative Biology 47(6): 799-807.

Jones G. 1999. Scaling of echolocation call parameters in bats. Journal of Experimental Biology 202(23): 3359-3367.

Jones G., Holderied M. W. 2007. Bat echolocation calls: adaptation and convergent evolution. Proceedings of the Royal Society of London, Series B: Biological Sciences 274(1612):905-912.

Jordão J. M., Cronin T. W., Oliveira R. F. 2007. Spectral sensitivity of four species of fiddler crabs (Uca pugnax, Uca pugilator, Uca vomeris and Uca tangeri) measured by in situ micro-spectrophotometry. Journal of Experimental Biology 210(3):447-453.

Kimchi T., Etienne A. S., Terkel J. 2004. A subterranean mammal uses the magnetic compass for path integration. Proceedings of the National Academy of Sciences USA 101(4):1105-1109.

Kingston T., Rossiter S. J. 2004. Harmonic-hopping in Wallacea's bats. Nature 429(6992):654-657.

Klump G. M. 1996. Bird communication in the noisy world. Pages 321-338 in Ecology and Evolution of Acoustic Communication in Birds, edited by D. E. Kroodsma and E. H. Miller. Ithaca (NY): Cornell University Press.

Koehl M. A. R., Koseff J. R., Crimaldi J. P., McCay M. G., Cooper T., Wiley M. B., Moore P. A. 2001. Lobster sniffing: antennule design and hydrodynamic filtering of information in an odor plume. Science 294(5548):1948-1951.

Krijnen G. J. M., Dijkstra M., van Baar J. J., Shankar S. S., Kuipers W.J., de Boer R. J. H., Altpeter D., Lammerink T. S. J., Wiegerink R. 2006. MEMS based hair flow-sensors as model systems for acoustic perception studies. Nanotechnology 17(4):S84S89.

Kroodsma D. E., Miller E. H., editors. 1996. Ecology and Evolution of Acoustic Communication in Birds. Ithaca (NY): Cornell University Press.
Lakes-Harlan R., Strau $\beta$ J. 2006. Developmental constraint of insect audition. Frontiers in Zoology 3:20.

Lakes-Harlan R., Stölting H., Stumpner A. 1999. Convergent evolution of insect hearing organs from a preadaptive structure. Proceedings of the Royal Society of London, Series B: Biological Sciences 266(1424): 1161-1167.

Land M. F. 1989. Variations in the structure and design of compound eyes. Pages 90-111 in Facets of Vision, edited by D. G. Stavenga and R. C. Hardie. Berlin (Germany): Springer.

Land M. F., Nilsson D.-E. 2002. Animal Eyes. Oxford (UK): Oxford University Press.

Lande R. 1981. Models of speciation by sexual selection on polygenic traits. Proceedings of the National Academy of Sciences USA 78(6):3721-3725.

Lavagnino L. J., Anholt R. H. H., Fanara J. J. 2008. Variation in genetic architecture of olfactory behaviour among wild-derived populations of Drosophila melanogaster. Journal of Evolutionary Biology 21:988-996.

Lavoué S., Sullivan J. P., Arnegard M. E., Hopkins C. D. 2008. Differentiation of morphology, genetics and electric signals in a region of sympatry between sister species of African electric fish (Mormyridae). Journal of Evolutionary Biology 21(4):1030-1045.

Leal M., Fleishman L. J. 2002. Evidence for habitat partitioning based on adaptation to environmental light in a pair of sympatric lizard species. Proceedings of the Royal Society of London, Series B: Biological Sciences 269(1489):351-359.

Levene J. S., MacNichol E. F. 1979. Visual pigments in teleost fishes: effects of habitat, microhabitat, and behavior on visual system evolution. Sensory Processes 3:95-131.

Li G., Wang J., Rossiter S. J., Jones G., Cotton J. A., Zhang S. 2008. The hearing gene Prestin reunites echolocating bats. Proceedings of the National Academy of Sciences USA 105(37):13959-13964.

Lim M. L. M., Sodhi N. S., Endler J. A. 2008 Conservation with sense. Science 319(5861):281.

Linkenhoker B. A., Knudsen E. I. 2002. Incremental training increases the plasticity of the auditory space map in adult barn owls. Nature 419(6904): 293-296.

Löfstedt C., Lanne B. S., Löfqvist J., Appelgren M., Bergström G. 1985. Individual variation in the pheromone of the turnip moth Agrotis segetum. Journal of Chemical Ecology 11(9):1181-1196.

Longcore T., Rich C. 2004. Ecological light pollution. Frontiers in Ecology and the Environment 2(4):191198.

Lukowiak K., Weeks J., editors. 2008. Neurosensory ecology. Journal of Experimental Biology 211:1705.

Lythgoe J. N. 1979. The Ecology of Vision. Oxford (UK): Oxford University Press. 
Lythgoe J. N. 1984. Visual pigments and environmental light. Vision Research 24(11):1539-1550.

Magal C., Dangles O., Caparroy P., Casas J. 2006. Hair canopy of cricket sensory system tuned to predator signals. Journal of Theoretical Biology 241 (3):459-466.

Manley G. A., Popper A. N., Fay R. R., editors. 2004. Evolution of the Vertebrate Auditory System. New York: Springer.

McClelland B. E., Wilczynski W., Ryan M. J. 1998. Intraspecific variation in laryngeal and ear morphology in male cricket frogs (Acris crepitans). Biological Journal of the Linnean Society 63(1):51-67.

McDonald C. G., Hawryshyn C. W. 1995. Intraspecific variation of spectral sensitivity in three-spine stickleback (Gasterosteus aculeatus) from different photic regimes. Journal of Comparative Physiology A: Neuroethology, Sensory, Neural, and Behavioral Physiology 176(2):255-260.

McFarland W. N., Munz F. W. 1975. The evolution of photopic visual pigments in fishes. Vision Research 15(10):1071-1080.

McNamara K. J. 1997. Shapes of Time: The Evolution of Growth and Development. Baltimore (MD): Johns Hopkins University Press.

Melin A. D., Fedigan L. M., Hiramatsu C., Kawamura S. 2008. Polymorphic color vision in white-faced capuchins (Cebus capucinus): is there foraging niche divergence among phenotypes? Behavioral Ecology and Sociobiology 62(5):659-670.

Melin A. D., Fedigan L. M., Hiramatsu C., Sendall C., Kawamura S. 2007. Effects of colour vision phenotype on insect capture by a free-ranging population of white-faced capuchins, Cebus capucinus. Animal Behaviour 73(1):205-214.

Miller L. A., Surlykke A. 2001 How some insects detect and avoid being eaten by bats: tactics and countertactics of prey and predator. BioScience $51(7): 570-581$.

Morgan M. J., Adam A., Mollon J. D. 1992. Dichromats detect colour-camouflaged objects that are not detected by trichromats. Proceedings of the Royal Society of London, Series B: Biological Sciences 248(1323):291-295.

Mousseau T. A., Roff D. A. 1989. Geographic variability in the incidence and heritability of wing dimorphism in the striped ground cricket, Allonemobius fasciatus. Heredity 62(3):315-318.

Müller-Schwarze D. 2006. Chemical Ecology of Vertebrates. Cambridge (UK): Cambridge University Press.

Narins P. M., Hödl W., Grabul D. S. 2003. Bimodal signal requisite for agonistic behavior in a dartpoison frog, Epipedobates femoralis. Proceedings of the National Academy of Sciences USA 100(2):577-580.

Neuhofer D., Wohlgemuth S., Stumpner A., Ronacher B. 2008. Evolutionarily conserved coding properties of auditory neurons across grasshopper species. Pro- ceedings of the Royal Society of London, Series B: Biological Sciences 275(1646):1965-1974.

Neuweiler G. 1989. Foraging ecology and audition in echolocating bats. Trends in Ecology and Evolution 4(6):160-166.

Novales Flamarique I. 2000. The ontogeny of ultraviolet sensitivity, cone disappearance and regeneration in the sockeye salmon Oncorhyncus nerka. Journal of Experimental Biology 203(7):1161-1172.

Oakley T. H., Cunningham C. W. 2002. Molecular phylogenetic evidence for the independent evolutionary origin of an arthropod compound eye. Proceedings of the National Academy of Sciences USA 99(3):1426-1430.

Opstad R., Rogers S. M., Behmer S. T., Simpson S. J. 2004. Behavioural correlates of phenotypic plasticity in mouthpart chemoreceptor numbers in locusts. Journal of Insect Physiology 50(8):725-736.

Ord T. J., Peters R. A., Clucas B., Stamps J. A. 2007. Lizards speed up visual displays in noisy motion habitats. Proceedings of the Royal Society of London, Series B: Biological Sciences 274(1613):1057-1062.

Osipov G. V., Kurths J., Zhou C. 2007. Synchronization in Oscillatory Networks. Berlin (Germany): Springer.

Parker A. R., McKenzie D. R., Ahyong S. T. 1998. A unique form of light reflector and the evolution of signalling in Ovalipes (Crustacea: Decapoda: Portunidae). Proceedings of the Royal Society of London, Series B: Biological Sciences 265(1399):861-867.

Partridge J. C. 1989. The visual ecology of avian cone oil droplets. Journal of Comparative Physiology A: Neuroethology, Sensory, Neural, and Behavioral Physiology 165(3):415-426.

Pasteels J. M., Grégoire J. C., Rowell-Rahier M. 1983. The chemical ecology of defense in arthropods. Annual Review of Entomology 28:263-289.

Peremans H., Reijniers J. 2005. The CIRCE head: a biomimetic sonar system. Pages 283-288 in Artificial Neural Networks, Biological Inspirations-ICANN 2005, edited by W. Duch et al. Berlin (Germany): Springer.

Phelps S. M. 2007. Sensory ecology and perceptual allocation: new prospects for neural networks. Philosophical Transactions of the Royal Society of London, Series B: Biological Sciences 362(1479):355-367.

Pichaud F., Briscoe A., Desplan C. 1999. Evolution of color vision. Current Opinion in Neurobiology 9(5): 622-627.

Plachetzki D. C., Oakley T. H. 2007. Key transitions during animal eye evolution: novelty, tree thinking, co-option, and co-duplication. Integrative and Comparative Biology 47:759-769.

Prum R. O., Torres R. 2003. Structural colouration of avian skin: convergent evolution of coherently scattering dermal collagen arrays. Journal of Experimental Biology 206(14):2409-2429.

Rabin L. A., Greene C. M. 2002. Changes to acoustic 
communication systems in human-altered environments. Journal of Comparative Psychology 116(2): 137-141.

Rabin L. A., McCowan B., Hooper S. L., Owings D. H. 2003. Anthropogenic noise and its effect on animal communication: an interface between comparative psychology and conservation biology. International Journal of Comparative Psychology 16:172192.

Raine N. E., Chittka L. 2007. The adaptive significance of sensory bias in a foraging context: floral colour preferences in the bumblebee Bombus terrestris. PLoS One 2(6):e556.

Raine N. E., Ings T. C., Dornhaus A., Saleh N., Chittka L. 2006. Adaptation, genetic drift, pleiotropy, and history in the evolution of bee foraging behavior. Advances in the Study of Behavior 36:305-354.

Rasmont P., Coppée A., Michez D., De Meulemeester T. 2008. An overview of the Bombus terrestris (L. 1758) subspecies (Hymenoptera: Apidae). Annales de la Société Entomologique de France 44(1):243-250.

Ratcliffe J. M., Fullard J. H. 2005. The adaptive function of tiger moth clicks against echolocating bats: an experimental and synthetic approach. Journal of Experimental Biology 208(24):4689-4698.

Regan B. C., Julliot C., Simmen B., Viénot F., CharlesDominique P., Mollon J. D. 2001. Fruits, foliage and the evolution of primate colour vision. Philosophical Transactions of the Royal Society of London, Series B: Biological Sciences 356(1407):229-283.

Reznick D. A., Bryga H., Endler J. A. 1990. Experimentally induced life-history evolution in a natural population. Nature 346(6282):357-359.

Rheinlaender J., Römer H. 1986. Insect hearing in the field. I. The use of identified nerve cells as 'biological microphones.' Journal of Comparative Physiology A: Neuroethology, Sensory, Neural, and Behavioral Physiology 158(5):647-651.

Richardson J. W., Greene C. R., Jr., Malme C. I., Thomson D. H. 1998. Marine Mammals and Noise. New York: Academic Press.

Robert D., Amoroso J., Hoy R. R. 1992. The evolutionary convergence of hearing in a parasitoid fly and its cricket host. Science 258(5085):1135-1137.

Roeder K. D., Treat A. E. 1957. Ultrasonic reception by the tympanic organs of noctuid moths. Journal of Experimental Zoology 134:127-158.

Romeo J. T., editor. 2005. Chemical Ecology and Phytochemistry of Forest Ecosystems. Amsterdam (The Netherlands): Elsevier Science.

Römer H. 1998. The sensory ecology of acoustic communication in insects. Pages 63-96 in Comparative Hearing: Insects, Springer Handbook of Auditory Research, Volume 10, edited by R. R. Hoy et al. New York: Springer.

Römer H., Bailey W. J. 1986. Insect hearing in the field. II. Spacing behaviour and related acoustic cues for the male Mygalopsis marki (Tettigoniidae). Journal of Comparative Physiology A: Neuroethology, Sensory, Neural, and Behavioral Physiology 159(5): 627-638.

Römer H., Lewald J. 1992. High-frequency sound transmission in natural habitats: implications for the evolution of insect acoustic communication. Behavioual Ecology and Sociobiology 29(4):437-444.

Rosenthal G. G. 2007. Spatiotemporal dimensions of visual signals in animal communication. Annual Review of Ecology, Evolution, and Systematics 38:155178.

Ross D. 1987. Mechanics of Underwater Noise. Los Altos (CA): Peninsula Publishing.

Rowe C., Guilford T. 1999. The evolution of multimodal warning displays. Evolutionary Ecology 13(7-8): 655-671.

Rubel E. W. 1984. Ontogeny of auditory system function. Annual Review of Physiology 46:213-229.

Russell D. A., Wilkens L. A., Moss F. 1999. Use of behavioral stochastic resonance by paddlefish for feeding. Nature 402(6759):219-223.

Ryan M. J. 1983. Sexual selection and communication in a Neotropical frog, Physalaemus pustulosus. Evolution 39:261-272.

Ryan M. J. 1990. Sensory systems, sexual selection, and sensory exploitation. Pages 157-195 in Oxford Surveys in Evolutionary Biology, Volume 7, edited by D. Futuyama and J. Antonovics. New York: Oxford University Press.

Ryan M. J. 2007. Sensory ecology: see me, hear me. Current Biology 17(23):R1019-R1021.

Ryan M. J., Rand A. S. 1999. Phylogenetic influences on mating call preferences in female túngara frogs (Physalaemus pustulosus). Animal Behaviour 57(4): 945-956.

Salzburger W., Niederstätter H., Brandstätter A., Berger B., Parson W., Snoeks J., Sturmbauer C. 2006. Colour-assortative mating among populations of Tropheus moorii, a cichlid fish from Lake Tanganyika, East Africa. Proceedings of the Royal Society of London, Series B: Biological Sciences 273(1584):257-266.

Savchenko A., Kraft T. W., Molokanova E., Kramer R. H. 2001. Growth factors regulate phototransduction in retinal rods by modulating cyclic nucleotide-gated channels through phosphorylation of a specific tyrosine residue. Proceedings of the National Academy of Sciences USA 98(10):5880-5885.

Schaub A., Ostwald J., Siemers B. M. 2008. Foraging bats avoid noise. Journal of Experimental Biology 211(19):3174-3180.

Searcy W. A., Nowicki S. 2005. The Evolution of Animal Communication: Reliability and Deception in Signaling Systems. Princeton (NJ): Princeton University Press.

Seehausen O., Terai Y., Magalhaes I. S., Carleton K. L., Mrosso H. D. J., Miyagi R., van der Sluijs I., 
et al. 2008. Speciation through sensory drive in cichlid fish. Nature 455(7213):620-626.

Seehausen O., van Alphen J. J. M., Witte F. 1997. Cichlid fish diversity threatened by eutrophication that curb sexual selection. Science 277(5333):1808-1811.

Shand J., Davies W. L., Thomas N., Balmer L., Cowing J. A., Pointer M., Carvalho L. S., Trezise A. E. O., Collin S. P., Beazley L. D., Hunt D. M. 2008. The influence of ontogeny and light environment on the expression of visual pigment opsins in the retina of the black bream, Acanthopagrus butcheri. Journal of Experimental Biology 211(9):1495-1503.

Shand J., Partridge J. C., Archer S. N., Potts G. W., Lythgoe J. N. 1988. Spectral absorbance changes in the violet/blue sensitive cones of the juvenile pollack, Pollachius pollachius. Journal of Comparative Physiology A: Neuroethology, Sensory, Neural, and Behavioral Physiology 163(5):699-703.

Siddiqi A., Cronin T. W., Loew E. R., Vorobyev M., Summers K. 2004. Interspecific and intraspecific views of color signals in the strawberry poison frog, Dendrobates pumilio. Journal of Experimental Biology 207(14):2471-2485.

Siemers B. M., Güttinger R. 2006. Prey conspicuousness can explain apparent prey selectivity. Current Biology 16(15):R157-R159.

Siemers B. M., Schnitzler H.-U. 2004. Echolocation signals reflect niche differentiation in five sympatric congeneric bat species. Nature 429 (6992) :657661.

Silverstein R. M. 1981. Pheromones: background and potential for use in insect pest control. Science 213(4514):1326-1332.

Skorupski P., Doering T., Chittka L. 2007. Photoreceptor spectral sensitivity in island and mainland populations of the bumblebee, Bombus terrestris. Journal of Comparative Physiology A: Neuroethology, Sensory, Neural, and Behavioral Physiology 193(5): 485-494.

Slabbekoorn H., Ripmeester E. A. P. 2008. Birdsong and anthropogenic noise: implications and applications for conservation. Molecular Ecology 17(1): 72-83.

Smith A. C., Buchanan-Smith H. M., Surridge A. K., Osorio D., Mundy N. I. 2003. The effect of colour vision status on the detection and selection of fruits by tamarins (Saguinus spp.). Journal of Experimental Biology 206(18):3159-3165.

Smith C., Barber R., Wootton J., Chittka L. 2004. A receiver bias in the origin of three-spined stickleback mate choice. Proceedings of the Royal Society of London, Series B: Biological Sciences 271(1542):949955 .

Smith C. U. M. 2000. Biology of Sensory Systems. Hoboken (NJ): Wiley.

Snyder J. B., Nelson M. E., Burdick J. W., MacIver M. A. 2007. Omnidirectional sensory and motor volumes in electric fish. PLoS Biology 5(11):6712683.

Sondheimer E. H., Simeons J. B., Bonner J. T. 1970. Chemical Ecology. New York: Academic Press.

Spaethe J., Briscoe A. D. 2004. Early duplication and functional diversification of the opsin gene family in insects. Molecular Biology and Evolution 21(8): 1583-1594.

Spaethe J., Chittka L. 2003. Interindividual variation of eye optics and single object resolution in bumblebees. Journal of Experimental Biology 206(19):34473453 .

Spangler H. G. 1988. Moth hearing, defense, and communication. Annual Review of Entomology 33: 59-81.

Springer M. S., Teeling E. C., Madsen O., Stanhope M. J., de Jong W. W. 2001. Integrated fossil and molecular data reconstruct bat echolocation. Proceedings of the National Academy of Sciences USA 98(11):6241-6246.

Stacey M. T., Mead K. S., Koehl M. A. R. 2002. Molecule capture by olfactory antennules: mantis shrimp. Journal of Mathematical Biology 44(1):1-30.

Stuart-Fox D., Moussalli A., Whiting M. J. 2007. Natural selection on social signals: signal efficacy and the evolution of chameleon display coloration. American Naturalist 170(6):916-930.

Stumpner A., von Helversen D. 2001. Evolution and function of auditory systems in insects. Naturwissenschaften 88:159-170.

Su K. F., Meier R., Jackson R. R., Hardland D. P., Li D. 2007. Convergent evolution of eye ultrastructure and divergent evolution of vision-mediated predatory behaviour in jumping spiders. Journal of Evolutionary Biology 20(4):1478-1489.

Sun J. W. C., Narins P. M. 2005. Anthropogenic sounds differentially affect amphibian call rate. Biological Conservation 121(3):419-427.

Suter R. B. 2003. Trichobothrial mediation of an aquatic escape response: directional jumps by the fishing spider, Dolomedes triton, foil frog attack. Journal of Insect Science 3:19.

Théry M., Casas J. 2002. Predator and prey views on spider camouflage. Nature 415(6868):133.

Thomas J. A., Moss C. F., Vater M. 2002. Echolocation in Bats and Dolphins. Chicago (IL): University Chicago Press.

Triblehorn J. D., Yager D. D. 2005. Acoustic interactions between insects and bats: a model for the interplay of neural and ecological specialization. Pages 77-104 in Ecology of Predator-Prey Interactions, edited by P. Barbosa and I. Castellanos. New York: Oxford University Press.

Triblehorn J. D., Yager D. D. 2006. Wind generated by an attacking bat: anemometric measurements and detection by the praying mantis cercal system. Journal of Experimental Biology 209(8):1430-1440. 
Vet L. E. M., Dicke M. 1992. Ecology of infochemical use by natural enemies in a tritrophic context. Annual Review of Entomology 37:141-172.

Vogel E. R., Neitz M., Dominy N. J. 2007. Effect of color vision phenotype on the foraging of wild white-faced capuchins, Cebus capucinus. Behavioual Ecology 18(2):292-297.

von Helversen D., Balakrishnan R., von Helversen O. 2004. Acoustic communication in a duetting grasshopper: receiver response variability, male strategies and signal design. Animal Behaviour 68(1): 131-144.

Ward A. J. W., Duff A. J., Horsfall J. S., Curie S. 2008. Scents and scents-ability: pollution disrupts chemical social recognition and shoaling in fish. Proceedings of the Royal Society of London, Series B: Biological Sciences 275(1630):101-105.

Warrant E. J. 2001. The design of compound eyes and the illumination of natural habitats. Pages 187213 in Ecology of Sensing, edited by F. G. Barth and A. Schmid. Berlin (Germany): Springer.

Warrant E. J. 2004. Vision in the dimmest habitats on earth. Journal of Comparative Physiology A: Neuroethology, Sensory, Neural, and Behavioral Physiology 190 (10):765-789.

Weissburg M. J. 2005. Introduction. Marine Ecology Progress Series 287:263-265.

Weisser W. W., Braendle C., Minoretti N. 1999. Predator-induced morphological shift in the pea aphid (Acyrthosiphon pisum). Proceedings of the Royal Society of London, Series B: Biological Sciences 266(1424): 1175-1182.

Werner E. E., Gilliam J. F. 1984. The ontogenetic niche and species interactions in size-structured populations. Annual Review of Ecology and Systematics 15:393-425.

Wickham S., Large M. C. J., Poladian L., Jermiin L. S. 2006. Exaggeration and suppression of iridescence: the evolution of two-dimensional butterfly structural colours. Journal of the Royal Society Interface 3(6):99-108.

Wiese K., Gribakin F. G., Popov A. V. 1992. Sensory Systems of Arthropods. Basel (Switzerland): Birkhäuser.

Wilczynski W., Ryan M. J. 1988. The amphibian auditory system as a model for neurobiology, behavior and evolution. Pages 3-12 in The Evolution of the
Amphibian Auditory System, edited by B. Fritzsch et al. New York: John Wiley and Sons.

Wilczynski W., Ryan M. J. 1999. Geographic variation in animal communication systems. Pages 234-261 in Geographic Diversification of Behavior: An Evolutionary Perspective, edited by S. A. Foster and J. Endler. Oxford (UK): Oxford University Press.

Wilczynski W., Ryan M. J., Rand A. S. 2001. Evolution of calls and auditory tuning in the Physalaemus species group. Brain, Behavior and Evolution 58(3): 137-151.

Wilkens H., Meyer M. 1992. Eye formation and regression during early ontogeny in cave fish. Pages 185-192 in Trends in Ichthyology, edited by J. H. Schröder et al. London (UK): Blackwell Scientific Publications.

Witzgall P., Stelinski L., Gut L., Thomson D. 2008. Codling moth management and chemical ecology. Annual Review of Entomology 53:503-522.

Wood P., Partridge J. C., Degrip W. J. 1992. Rod visual pigment changes in the elver of the eel Anguilla anguilla $\mathrm{L}$. measured by microspectrophotometry. Journal of Fish Biology 41(4):601-611.

Wyatt T. D. 2003. Pheromones and Animal Behaviour: Communication by Smell and Taste. Cambridge (UK): Cambridge University Press.

Yager D. D., Svenson G. J. 2008. Patterns of praying mantis auditory system evolution based on morphological, molecular, neurophysiological, and behavioural data. Biological Journal of the Linnean Society 94(3):541-568.

Yokoyama S., Yokoyama R. 1996. Adaptive evolution of photoreceptors and visual pigments in vertebrates. Annual Review of Ecology and Systematics 27: 543-567.

Zakon H. H., Zwickl D. J., Lu Y., Hillis D. M. 2008. Molecular evolution of communication signals in electric fish. Journal of Experimental Biology 211(11): 1814-1818.

Zeil J., Hemmi J. M. 2006. The visual ecology of fiddler crabs. Journal of Comparative Physiology A: Neuroethology, Sensory, Neural, and Behavioral Physiology 192(1):1-25.

Zeil J., Hofmann M. I., Chahl J. S. 2003. Catchment areas of panoramic snapshots in outdoor scenes. Journal of the Optical Society of America A 20(3):450469. 